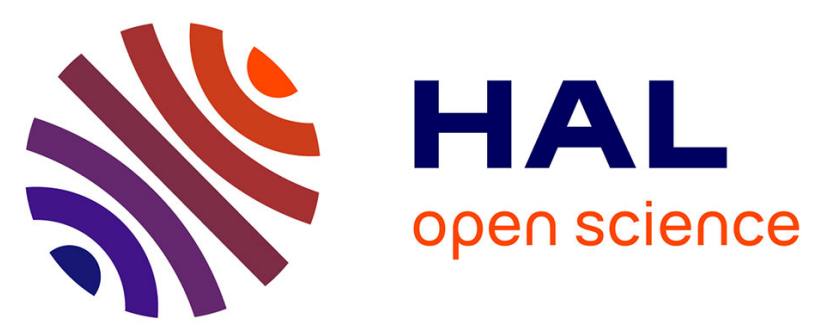

\title{
Structural Analysis of Uranyl Complexation by the EF-Hand Motif of Calmodulin: Effect of Phosphorylation
}

Sandrine Sauge-Merle, Florian Brulfert, Romain Pardoux, Pier Lorenzo Solari, David Lemaire, Samir Safi, Philippe Guilbaud, Eric Simoni, Mohamed Larbi L Merroun, C. Berthomieu

\section{To cite this version:}

Sandrine Sauge-Merle, Florian Brulfert, Romain Pardoux, Pier Lorenzo Solari, David Lemaire, et al.. Structural Analysis of Uranyl Complexation by the EF-Hand Motif of Calmodulin: Effect of Phosphorylation. Chemistry - A European Journal, 2017, 23 (61), pp.15505 - 15517. 10.1002/chem.201703484. hal-01794613

\section{HAL Id: hal-01794613 \\ https://hal-amu.archives-ouvertes.fr/hal-01794613}

Submitted on 17 May 2018

HAL is a multi-disciplinary open access archive for the deposit and dissemination of scientific research documents, whether they are published or not. The documents may come from teaching and research institutions in France or abroad, or from public or private research centers.
L'archive ouverte pluridisciplinaire HAL, est destinée au dépôt et à la diffusion de documents scientifiques de niveau recherche, publiés ou non, émanant des établissements d'enseignement et de recherche français ou étrangers, des laboratoires publics ou privés. 


\title{
Structural Analysis of Uranyl Complexation by the EF-Hand Motif of Calmodulin: Effect of Phosphorylation
}

\author{
S. Sauge-Merle , F. Brulfert, R.Pardoux, P. L. Solari, D. Lemaire, S.Safi, P.Guilbaud, E. \\ Simoni, M.L. Merroun, C.Berthomieu
}

\section{$\underline{\text { Abstract }}$}

Better understanding of uranyl-protein interactions is a prerequisite to predict uranium chemical toxicity in cells. The EF-hand motif of the calmodulin site I is about thousand times more affine for uranyl than for calcium, and threonine phosphorylation increases the uranyl affinity by two orders of magnitude at $\mathrm{pH}$ 7. In this study, we confront X-ray absorption spectroscopy with Fourier transform infrared (FTIR) spectroscopy, time-resolved laser-induced fluorescence spectroscopy (TRLFS), and structural models obtained by molecular dynamics simulations to analyze the uranyl coordination in the native and phosphorylated calmodulin site I. For the native site I, extended X-ray absorption fine structure (EXAFS) data evidence a short $\mathrm{U}-\mathrm{O}_{\text {eq }}$ distance, in addition to distances compatible with mono- and bidentate coordination by carboxylate groups. Further analysis of uranyl speciation by TRLFS and thorough investigation of the fluorescence decay kinetics strongly support the presence of a hydroxide uranyl ligand. For a phosphorylated site I, the EXAFS and FTIR data support a monodentate uranyl coordination by the phosphoryl group and strong interaction with mono- and bidentate carboxylate ligands. This study confirms the important role of a phosphoryl ligand in the stability of uranyl-protein interactions. By evidencing a hydroxide uranyl ligand in calmodulin site I, this study also highlights the possible role of less studied ligands as water or hydroxide ions in the stability of protein-uranyl complexes.

\section{$\underline{\text { Introduction }}$}

Uranium is a naturally occurring radioelement present in various chemical forms and oxidation states in soils, rocks, and oceans, which has been increasingly used during the last century for nuclear energy production and for a number of industrial and military applications. Uranium presents both chemical and radiological toxicity to living organisms and accumulates notably in kidneys and bones. 1 The chemical toxicity of uranium is associated with its direct interaction with biological molecules and biochemical processes. Comprehensive understanding of these molecular interactions is a prerequisite to better assess and predict toxicity mechanisms. In particular, it is essential to better understand mechanisms governing the interaction of uranium with proteins, and to decipher correlations between the protein structures and their affinity to uranium.

In recent years, several studies aimed at identifying protein targets of uranium $\underline{2}$ or at analyzing molecular details of these interactions. $\underline{3}$ Few quantitative thermodynamic studies have investigated the binding properties of uranyl with proteins or peptides, $\underline{3 \mathrm{c}}, \underline{3 \mathrm{e}}, \underline{4}$ which is however of primary importance to better assess uranium speciation in complex biological 
contexts. In addition, there are only few three-dimensional structures related to characterized uranyl binding sites in proteins. $\underline{4 c}, \underline{5}$ To unravel structure-properties relationships in uraniumprotein complexes, structural information is often obtained by using complementary spectroscopic techniques, such as X-ray absorption spectroscopy (XAS), vibrational spectroscopy, or time-resolved laser-induced fluorescence spectroscopy (TRLFS), and the use of theoretical models. $\underline{3 \mathrm{~b}}, \underline{3 \mathrm{e}}, \underline{3 \mathrm{f}}, \underline{4 \mathrm{~g}}, \underline{6}$ In particular, extended X-ray absorption fine structure (EXAFS) spectroscopy at the uranium $\mathrm{L}_{\text {III }}$ edge has been successfully applied to analyze the uranium coordination in various compounds, including proteins and peptides $\underline{3 \mathrm{~b}}, \underline{3 \mathrm{e}}, \underline{3 \mathrm{f}}, \underline{6 \mathrm{c}}, \underline{7}$ and is particularly useful to analyze properties of metal sites in solution.

Important information on the molecular determinants of the affinity of proteins for uranyl has also been obtained by engineering of proteins or peptides. $\underline{3 \mathrm{c}}, \underline{3 \mathrm{f}}, \underline{4 \mathrm{~b}}-\underline{4 \mathrm{e}}, \underline{4 \mathrm{~g}}, \underline{4 \mathrm{~h}}, \underline{8} \mathrm{In}$ this respect, we targeted the EF-hand calcium binding motif of calmodulin to engineer variants with an enhanced affinity for uranyl. This motif comprises two alpha helices flanking a twelve amino acid long loop comprising the seven calcium ligands (Scheme 1 ). Calmodulin is organized in two domains each containing two interacting calcium binding motifs. By using the calmodulin $\mathrm{N}$-terminal domain as a stable structured template and a variant with only site I able to interact with metal cations (Scheme 1), we showed that site I is about thousand times more affine for uranyl than for calcium in the two proteins CaMWT and CaM1, differing by the nature of two amino acids at positions 10 and 11 of the calcium binding loop (Table $\underline{1}$ ). $\underline{3 \mathrm{c}}$ CaMWT and CaM1 have dissociation constants for uranyl in the nanomolar range $\left(K_{\mathrm{d}}=(25 \pm 6)\right.$ and $(32 \pm 7) \mathrm{nM}$, respectively, corresponding to $\log K_{c} \approx 7.5$ ), and for calcium in the micromolar range $\left(K_{\mathrm{d}}=(38.4 \pm 1)\right.$ and $(23.2 \pm 3) \mu \mathrm{M}$, respectively, corresponding to $\left.\log K_{\mathrm{c}} \approx 4.5\right) . \underline{3 \mathrm{c}}$
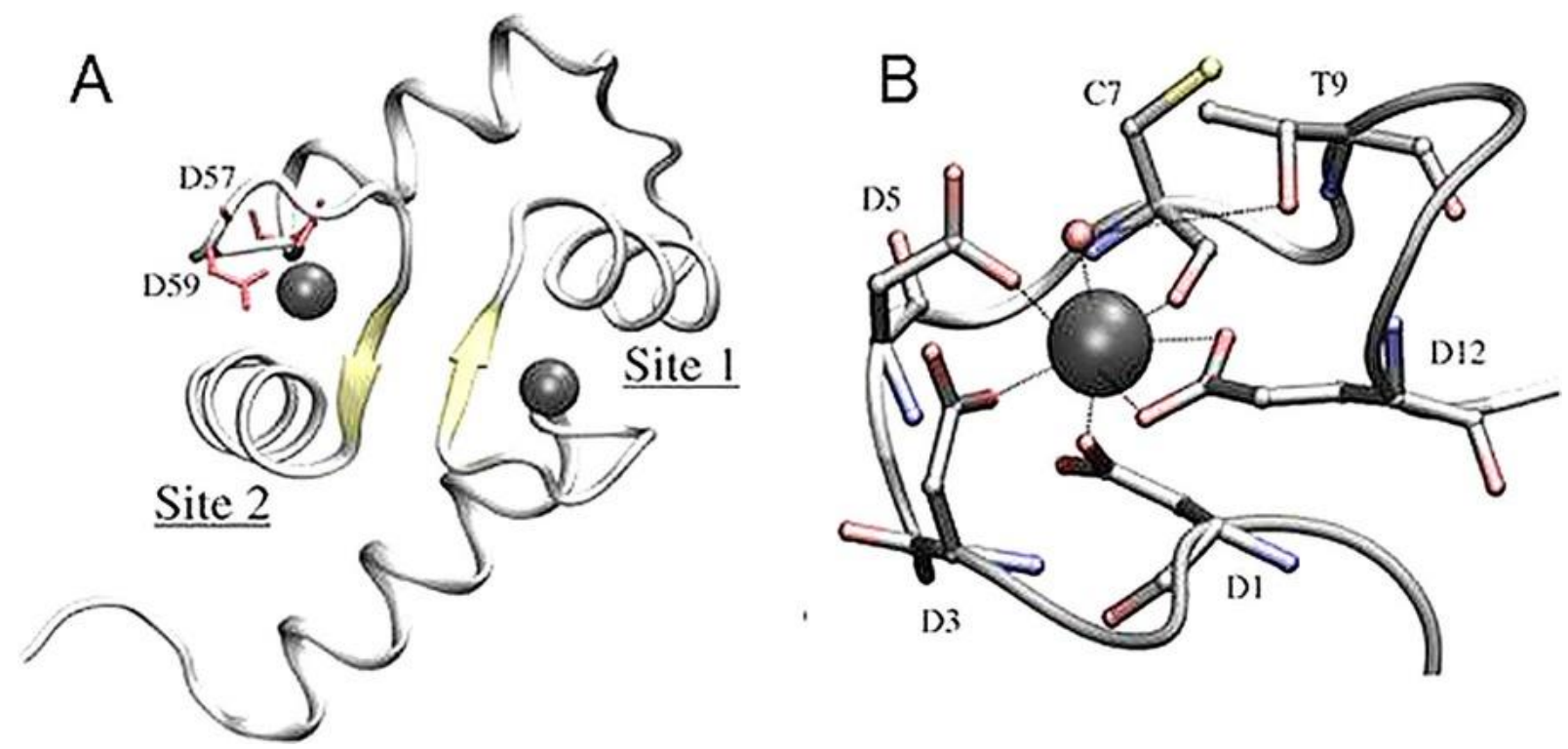

\section{Scheme 1}

A) N-terminal domain of the calmodulin of Paramecium tetraurelia (1EXR) with the two $\mathrm{Ca}^{2+}$ binding EF-hand motifs at site I and site II. The conserved aspartates D58 and D60 (positions 1 and 3 of the site II metal binding loop) were replaced by two alanine residues in the CaM peptides to impair metal binding at site II. B) Coordination of the calcium cation in site I involving the monodentate aspartates D1, D3, and D5 of the $\mathrm{Ca}^{2+}$ binding loop, the 
cysteine C7 carbonyl group, the bidentate glutamate E12, and a water molecule stabilized by the threonine T9 side chain.

Table 1. Sequences of the calmodulin at sites I and II.[a]

\begin{tabular}{|c|c|c|}
\hline Peptide & Sequence site I & Sequence site II \\
& $\mathbf{1 . 3 . 5 . 7 . 9 . 1 2}$ & $\mathbf{1 . 3 . 5 . 7 . 9 . 1 2}$ \\
CaMWT & DKDGDGYITTKE & AAAGNGTIDFPE \\
CaM1 & DKDGDGYITAAE & AAAGNGTIDFPE \\
CaM1P & DKDGDGYIT & \\
& & AAAAENGTIDFPE \\
\hline
\end{tabular}

- [a] The complete sequences of the calmodulin variants are given in Table S1 in the Supporting Information.

The dissociation constants of the uranyl-protein complexes were determined in the presence of iminodiacetate (IDA) as a competitor of known affinity for uranium $\underline{9}$ and can be compared with literature data obtained under similar experimental conditions. The calmodulin site I affinity for uranyl is comparable to that of the transcription factor NikR engineered for uranyl binding at

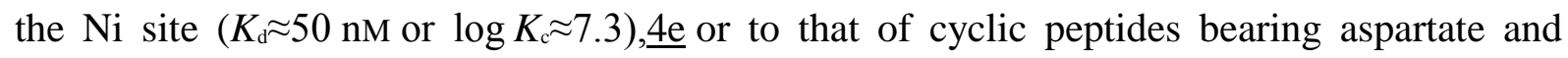
glutamate side chains as uranyl ligands $\left(K_{\mathrm{d}} \approx 4-8 \mathrm{nM}\right.$, or $\left.\log K_{\mathrm{c}}=8.1-8.4\right) . \underline{4 \mathrm{~b}}$

We further analyzed the effect of introducing a phosphoryl group in the metal binding loop on the affinity and selectivity of the EF-hand motif of the calmodulin site I for uranyl. $\underline{3 c I n d e e d, ~ a ~}$ strong uranyl affinity for phosphate or phosphoryl groups was exemplified in derivatives bearing bisphosphonate moieties $\underline{10}$ or by efficient binding of uranyl to phospholipids $\underline{7 a}, \underline{11}$ or phosphorylated proteins as phosvitin, phosphorylated S-layers, $\underline{3 \mathrm{~b}}, \underline{7 \mathrm{~b}}, \underline{12}$ and recently osteopontin involved in bone mineralization. $\underline{3 \mathrm{e}}, \underline{4 \mathrm{f}}, \underline{13}$

CaM1 was engineered to allow enzymatic phosphorylation of the threonine T9 of the binding loop (Table 1). $3 \mathrm{c}$ The affinity of the calmodulin site I for uranyl increased by two orders of magnitude at $\mathrm{pH} 7$ upon threonine phosphorylation, with a dissociation constant for the CaM1P-U complex of $K_{\mathrm{d}} \approx 320 \mathrm{pM}\left(\log K_{\mathrm{c}}=9.5\right) . \underline{3 \mathrm{c}}$ The affinity for calcium was not altered and the selectivity for uranyl versus calcium was greater than $10^{5}$ for CaM1P. The influence of the phosphoryl groups on the uranyl binding properties of cyclic peptides or short peptides was reported. $\underline{\mathrm{e}}, \underline{4 \mathrm{~g}}, \underline{4 \mathrm{~h}}, \underline{8}, \underline{14}$ Cyclic peptides with one or two phosphoserines and two to three glutamic acids as potential uranyl ligands showed $\log K_{\mathrm{c}}$ values ranging from 9.7 to 10.1 at $\mathrm{pH}$ $7 . \underline{4 \mathrm{~g}, \underline{4 \mathrm{~h}}}$ 
Structural data are missing to assess the uranyl coordination sphere and the structural origin of the strong affinity of CaM1P for uranyl as compared to non-phosphorylated CaM1. EXAFS data of the CaMWT-U complex revealed an uranyl-ligand distance too short to correspond to a monodentate carboxylate ligand, which could be modeled by the presence of a hydroxide ligand in the uranyl equatorial plane. $3 \mathrm{f}$ In the present study, we analyze the coordination sphere of uranyl in complexes formed with the non-phosphorylated CaM1 and the phosphorylated CaM1P peptides in solution to better assess the role of the phosphoryl group and of exogenous ligands as hydroxide on the stability of the uranyl-protein interactions.

\section{$\underline{\text { Results and Discussion }}$}

Structural determinants of the uranyl affinity of the CaM1P and CaM1 variants of the calmodulin N-terminal domain were analyzed by confronting the experimental data obtained by EXAFS spectroscopy at the U L LII edge, FTIR spectroscopy, and time-resolved laser-induced fluorescence spectroscopy (TRLFS) with structural models obtained by using molecular dynamics (MD) simulations.

The variants of the calmodulin $\mathrm{N}$-terminal domain comprise seventy-seven amino acids organized in a pair of EF-hand motifs defining the metal cation binding sites I and II (Scheme $\underline{1}$, Table 1 ). In these helix-loop-helix structural motifs, the metal ligands are within a twelve amino acid long sequence that includes the loop and the first turn of the second alpha helix (Scheme 1).15 In the variants studied here, metal binding at site II is impaired by the substitution of two aspartate ligands by two alanine residues (Table $\underline{1}$ ). $3 \mathrm{c}$ A tyrosine, introduced at position 7 of the metal binding loop of site I enables the thermodynamic characterization of uranyl binding by using the fluorescence of tyrosine. In CaM1, two alanine residues are introduced at positions 10 and 11 of site I to form a recognition site for the $\mathrm{CK}_{2}$ kinase, used for the in vitro phosphorylation of the threonine T9 (Table 1). $\underline{3 \mathrm{c}}$ This mutation is not present in the CaMWT variant. $\underline{3}$

\section{Molecular dynamics}

Structural models were obtained by MD simulations in the gas phase of the sequence encompassing the uranyl binding region and the beginning of the two flanking alpha helices. The rest of the peptide was kept frozen (Figure S1 in the Supporting Information). Trajectories were then analyzed in the stabilized energy configurations of the system. The maxima of the first peaks of the radial distribution functions (RDFs) between the uranyl molecule and the ligands are displayed in Table 2 . Structural models were obtained for different conformations of the uranyl complexes of the CaM1 and CaM1P peptides. For each peptide, simulations were performed starting from two conformers differing by the side-chain position of the tyrosine Y7. The resulting structural models differ at the uranyl coordination sphere but they display similar interaction energies with uranyl $\left(E_{\mathrm{i}}\right.$, Table $\left.\underline{2}\right)$. The interaction energies are higher for the complexes formed between the phosphorylated peptides and uranyl as compared to the nonphosphorylated one, and highest for peptides with a deprotonated phosphoryl group 
$\left(\mathrm{R}-\mathrm{OPO}_{3^{2-}}\right)$. This follows the trend observed experimentally, with dissociation constants $K_{\mathrm{d}}$ of $32 \mathrm{nM}$ for the CaM1-U complex, $5 \mathrm{nM}$ for the CaM1P-U complex at $\mathrm{pH}$ 6, and $0.32 \mathrm{nM}$ for the CaM1P-U complex at $\mathrm{pH} 7 . \underline{\mathrm{c}}$

Table 2. Uranyl cation coordination from MD simulations: position of the first peak (Dist) of the $R D F$ of the $U-O_{e q}$ bond and the corresponding coordination number ( $\mathrm{Nb}$ coord), and interaction energy $\left(E_{i}\right)$.

\begin{tabular}{|c|c|c|c|c|c|c|c|c|c|c|c|c|c|c|c|}
\hline & As & & Asp & & Asp & & $\begin{array}{l}\text { Gly } \\
\text { C= }\end{array}$ & & $\begin{array}{l}\text { Tyr } \\
\text { C= }\end{array}$ & & Thr & & Glu & & \multirow[t]{2}{*}{$\begin{array}{c}E_{\mathrm{i}}^{[\mathrm{b}]} \\
{[\mathrm{kJ}} \\
\left.\mathrm{mol}^{-1}\right]\end{array}$} \\
\hline & $\begin{array}{l}\mathrm{Nb} \\
\text { coord }\end{array}$ & $\begin{array}{c}\operatorname{Dist}^{[a]} \\
[\AA]]\end{array}$ & $\begin{array}{l}\mathrm{Nb} \\
\text { coord }\end{array}$ & $\begin{array}{l}\text { Dist } \\
[\AA]]\end{array}$ & $\begin{array}{l}\mathrm{Nb} \\
\text { coord }\end{array}$ & $\begin{array}{l}\text { Dist } \\
{[\AA]}\end{array}$ & $\begin{array}{c}\mathrm{Nb} \\
\text { coord }\end{array}$ & $\begin{array}{l}\text { Dist } \\
[\AA]]\end{array}$ & $\begin{array}{c}\mathrm{Nb} \\
\text { coord }\end{array}$ & $\begin{array}{l}\text { Dist } \\
[\AA]]\end{array}$ & $\begin{array}{c}\mathrm{Nb} \\
\text { coord }\end{array}$ & $\begin{array}{l}\text { Dist } \\
{[\AA]}\end{array}$ & $\begin{array}{c}\mathrm{Nb} \\
\text { coord }\end{array}$ & $\begin{array}{l}\text { Dist } \\
[\AA]]\end{array}$ & \\
\hline CaM1 conf. 1 & & & 11 & $\begin{array}{l}2.46 \\
2.46\end{array}$ & 10.9 & $\begin{array}{l}2.45 \\
2.65\end{array}$ & & & 1 & 2.52 & & & 1 & 2.48 & $\begin{array}{l}-976 \\
(\Delta 19)\end{array}$ \\
\hline CaM1 conf. 2 & 0.1 & 2.5 & $\begin{array}{c}0.97 \\
0.6\end{array}$ & $\begin{array}{l}2.42 \\
2.47\end{array}$ & $\begin{array}{c}1 \\
0.97\end{array}$ & $\begin{array}{l}2.45 \\
2.42\end{array}$ & & & 0.95 & 2.49 & & & 1 & 2.4 & $\begin{array}{l}-972 \\
(\Delta 31)\end{array}$ \\
\hline $\begin{array}{c}\mathrm{CaM}_{1 \mathrm{POH}}[\mathrm{c}] \\
\text { conf. } 1\end{array}$ & & & 11 & $\begin{array}{l}2.46 \\
2.58\end{array}$ & 11 & $\begin{array}{l}2.6 \\
2.6\end{array}$ & & & 1 & 2.54 & & & 11 & $\begin{array}{l}2.51 \\
2.57\end{array}$ & $\begin{array}{c}-1082 \\
(\Delta 12)\end{array}$ \\
\hline $\begin{array}{c}\text { CaM1POH[c] } \\
\text { conf. } 2\end{array}$ & & & 11 & $\begin{array}{l}2.45 \\
2.62\end{array}$ & 11 & $\begin{array}{l}2.49 \\
2.65\end{array}$ & 1 & 2.57 & & & & & 11 & $\begin{array}{l}2.55 \\
2.55\end{array}$ & $\begin{array}{c}-1080 \\
(\Delta 16)\end{array}$ \\
\hline $\begin{array}{l}\text { CaM1PO } \\
\text { monodentate }\end{array}$ & 0.7 & 2.41 & & & 11 & 2.51 & & & 0.3 & 2.58 & 1 & 2.33 & 1 & 2.45 & $\begin{array}{c}-1224 \\
(\Delta 36)\end{array}$ \\
\hline $\begin{array}{l}\text { CaM1Po[c] } \\
\text { bidentate }\end{array}$ & 1 & 2.44 & & & 1 & 2.37 & & & & & 11 & $\begin{array}{l}2.41 \\
2.49\end{array}$ & 1 & 2.4 & $\begin{array}{c}-1260 \\
(\Delta 24)\end{array}$ \\
\hline
\end{tabular}

- [a] Distance corresponding to the position of the first peak position of the RDF. Only distances smaller than $2.7 \AA$ are reported. Distances greater than $2.55 \AA$ are given in italics. [b] $E_{i}$ is the interaction energy calculated as the difference between the energies of the separated protein and the uranyl molecule and that of the peptide-uranyl complex. [c] CaM1POH corresponds to peptides in which the phosphoryl group is protonated, CaM1PO corresponds to peptides in which the phosphoryl group is deprotonated.

\section{CaM1P-uranyl complexes}

In the structural models obtained for the CaM1P-U complex (Figures $\underline{2} \mathrm{~A}-\mathrm{C}$ ), the phosphoryl group is found coordinated to uranyl only in its deprotonated dianionic $\mathrm{O}-\mathrm{PO}_{3^{2-}}$ form, and with monodentate (Figure $\underline{2} \mathrm{~A}$ ) or bidentate (Figure $\underline{2}$ B) configurations. For the configuration with a monodentate phosphoryl ligand, the coordination sphere of uranyl is completed with two monodentate (Asp1 and Glu12) and one bidentate (Asp5) carboxylate ligands (Table 2). For the configuration with a bidentate phosphoryl, the uranyl coordination sphere is completed with three monodentate carboxylate ligands from Asp1, Asp5, and Glu12. The coordination number of uranyl (i.e., five) and the uranyl- $\mathrm{O}_{\mathrm{eq}}$ distances are very similar for both models (Table $\underline{2}$ ). There is no evidence for the involvement of a peptide carbonyl group in the uranyl coordination. All uranyl- $\mathrm{O}_{\text {еq }}$ distances are shorter than $2.52 \AA$. 

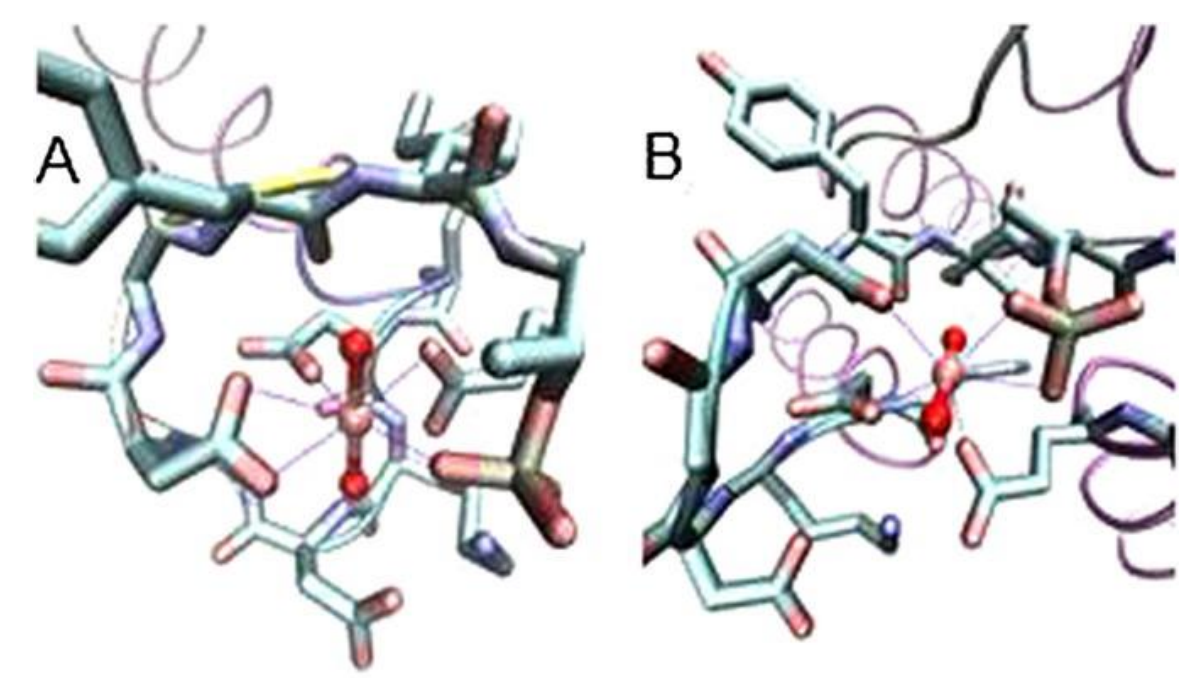

\section{Figure 1}
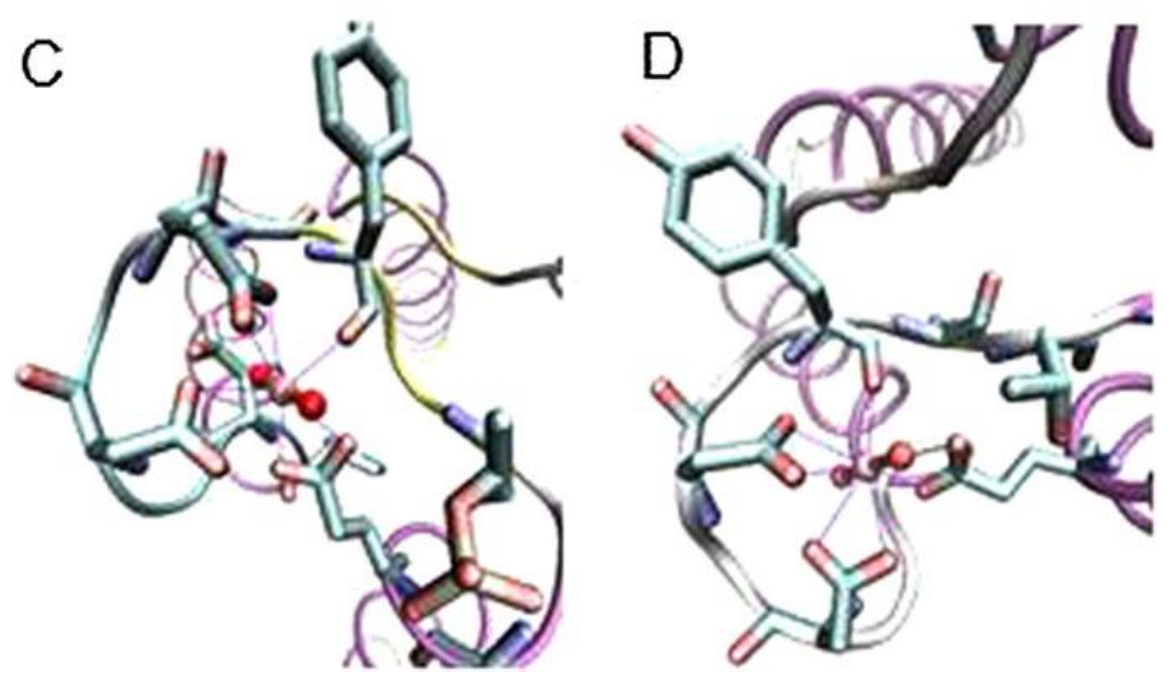

Structural models obtained by MD simulations for the CaM1P-U complex: A) with monodentate coordination of the deprotonated phosphoryl group, B) with bidentate coordination of the deprotonated phosphoryl group, and C) with a protonated phosphoryl group. D) Structural model of the CaM1-U complex (conformer 2). Snapshots selected for uranyl-ligand distances close to the distances obtained by the radial distribution function analyses reported in Table 2 .

In contrast, in the model with a protonated phosphoryl group, the phosphoryl is not interacting with the uranyl molecule (Figure 2 C, Table 2). In one conformer (i.e., conf. 2), uranyl is coordinated to monodentate carboxylate groups from Asp3 and Asp5 with two short $\mathrm{U}-\mathrm{O}_{\text {eq }}$ distances of 2.45-2.49 $\AA$. Three additional $\mathrm{U}-\mathrm{O}_{\text {eq }}$ interactions involve the bidentate Glu12, with $\mathrm{U}-\mathrm{O}_{\mathrm{eq}}$ distances of approximately $2.55 \AA$, and the peptide carbonyl group of Gly6 of $2.57 \AA$. In the second conformer, a peptide carbonyl ligand is provided by Tyr7, the carboxylate oxygen atoms of Glu12 are less equivalent, but those of Asp3 and Asp5 more symmetric (Table $\underline{2}$, Figure $\underline{2} \mathrm{C}$ ). The MD simulations reveal a high plasticity of uranyl coordination during the simulation, with uranyl coordinated either by the Tyr7 main chain carbonyl group or by a carboxylate ligand. 


\section{CaM1-uranyl complexes}

For the CaM1-U complexes, structural models corresponding to the mean distances in the simulations comprise five or six coordinating oxygen atoms in the equatorial plane of $\mathrm{UO}_{2}{ }^{2+}$. The $\mathrm{U}-\mathrm{O}_{\mathrm{eq}}$ distances are comprised between 2.4 and $2.52 \AA$. In both conformers, uranyl coordination involves Glu12 as a monodentate ligand, Asp3 as a bidentate ligand, and the carbonyl group of Tyr7. Depending on the conformer, the coordination sphere of uranyl is completed by Asp5 either as a monodentate or as a bidentate ligand (Table 2 ). Asp1 is not involved in the uranyl coordination.

Flexibility and movements of the coordinating residues were also observed in the MD simulations for the CaM1-U complex. The structural models obtained by the MD simulations were calculated in the gas phase and did not take into account possible coordination by solvent molecules or the influence of charged ions in solution on the structure of the metal center. The resulting models also depend on the starting conformer. Therefore, these models were taken as indicative models to be challenged by the experimental data obtained by FTIR, EXAFS, and TRLF spectroscopy.

\section{FTIR spectroscopy}

The asymmetric and symmetric stretching modes of carboxylate groups, that is, $v_{\mathrm{as}}\left(\mathrm{COO}^{-}\right)$and $v_{\mathrm{s}}\left(\mathrm{COO}^{-}\right)$, are excellent probes of their coordination to metals, including uranyl, and of their mode of binding as monodentate or bidentate ligands. 16 In the absorption range, in which carbonyl or carboxylate groups from uranyl ligands are expected to contribute, that is, $\tilde{\nu} \approx 1700-1350 \mathrm{~cm}^{-1}$, the infrared absorption of the samples are dominated by contributions from peptide bonds, with the amide I and amide II bands at $\tilde{\nu} \approx 1650$ and $1550 \mathrm{~cm}^{-1}$, respectively (Figure S2 A in the Supporting Information17). Because most of the amide bonds are not involved in the uranyl coordination, and because the secondary structure of the protein is conserved in the apo- and holo-forms, these bands contribute at the same infrared frequencies in samples with and without uranyl. In contrast, the IR signatures of the carboxylate or carbonyl and phosphoryl groups involved in uranyl coordination should differ significantly between the peptide samples without uranyl and the peptide-uranyl complexes. These later contributions are thus highlighted in calculated difference spectra, as shown in the "CaM1-U-minus- CaM1" FTIR difference spectrum given in Figure $\underline{3} \mathrm{~A}$. This spectrum was calculated from the absorption spectra obtained under exactly the same conditions and the difference spectrum is of high quality (see also Figure S2 B in the Supporting Information). 


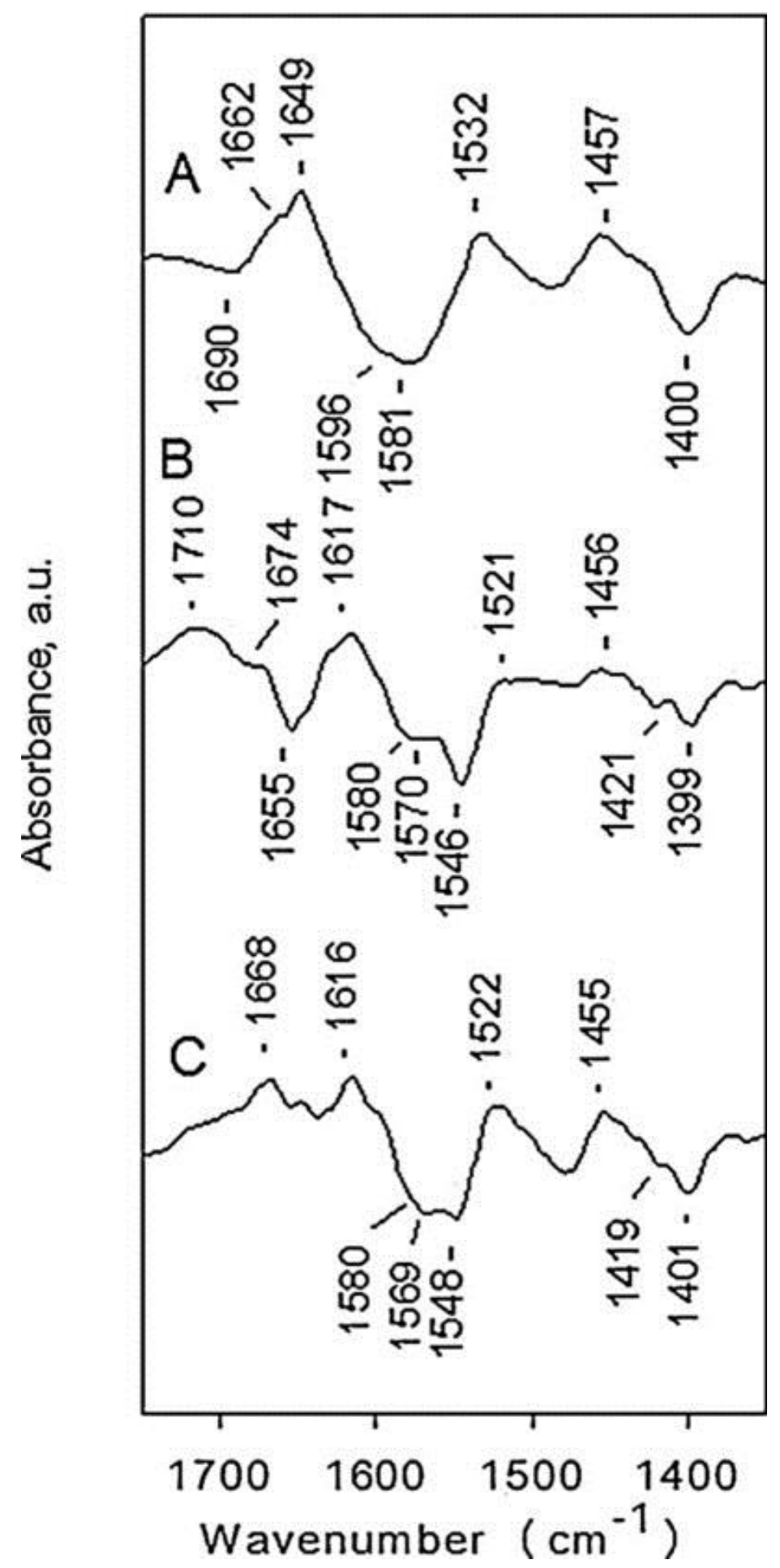

Figure 2

FTIR analysis of uranyl complexes formed at the calmodulin site I. A) CaM1-U-minus-CaM1 FTIR difference spectrum, CaMIP-U-minus-CaMIP FTIR difference spectrum recorded at: B) $\mathrm{pH}$ 6, and C) $\mathrm{pH} 7$.

Negative bands at $\tilde{\nu}=1596$ and $1581 \mathrm{~cm}^{-1}$ are typical for the $v_{\text {as }}\left(\mathrm{COO}^{-}\right)$modes of carboxylate groups in solution and the negative band at $\tilde{\nu}=1400 \mathrm{~cm}^{-1}$ is typical for the corresponding $v_{\mathrm{s}}\left(\mathrm{COO}^{-}\right)$mode. The two bands at $\tilde{\nu}=1596$ and $1581 \mathrm{~cm}^{-1}$ indicate that at least two carboxylate groups are involved in the uranyl coordination. 
In addition, the frequency of the $v_{\text {as }}\left(\mathrm{COO}^{-}\right)$mode of the Asp and Glu side chains are expected at slightly different frequencies, namely, $\tilde{\nu}=1584-1574$ and 1567-1560 $\mathrm{cm}^{-1}$ respectively. 18 The two bands observed in Figure $\underline{3} \mathrm{~A}$ thus suggest that side chains of Asp(s) and Glu are involved in the uranyl coordination. The small negative band at $\tilde{\nu}=1690$ $\mathrm{cm}^{-1}$ is in the frequency range of the amide $v(\mathrm{C}=\mathrm{O})$ modes. 17 It suggests that (at least) one peptide bond is sensitive to uranyl binding in CaM1. Positive bands are associated with the CaM1-U complex. A band at $\tilde{\nu}=919 \mathrm{~cm}^{-1}$ is assigned to the $v_{\text {as }}\left(U-\mathrm{O}_{a x}\right)$ stretching mode of uranyl (Figure S2 B in the Supporting Information, see also ref. $\underline{3 \mathrm{c}}$ ). Bands at $\tilde{\nu}=1532$ and $1457 \mathrm{~cm}^{-1}$ typically correspond to the $v_{\text {as }}$ and $v_{\mathrm{s}}$ modes of carboxylate groups involved in bidentate uranyl coordination. $\underline{16 \mathrm{a}}, \underline{19}$ The frequency difference $\Delta\left(\tilde{\nu}_{\mathrm{as}}-\tilde{\nu}_{\mathrm{s}}\right)=75 \mathrm{~cm}^{-1}$ is smaller than for carboxylate in solution and smaller than $100 \mathrm{~cm}^{-1}$, which is strongly indicative for a bidentate coordination to uranyl.16a In addition, the bands at $\tilde{\nu}=1662$ and $1649 \mathrm{~cm}^{-1}$ are in agreement with the $v_{\text {as }}\left(\mathrm{COO}^{-}\right)$modes of monodentate carboxylate ligands of uranyl. They could also correspond to a peptide $v(\mathrm{C}=\mathrm{O})$ mode involved in uranyl coordination, because the frequency of the $v(\mathrm{C}=\mathrm{O})$ mode is downshifted (here from $\tilde{\nu}=1690$ to 1662 or $1649 \mathrm{~cm}^{-1}$ ) are expected upon interaction of a carbonyl group with a metal cation. $\underline{20}$

The CaM1P-U-minus-CaM1P FTIR difference spectra were recorded at $\mathrm{pH} 6$ and 7 (Figures $\underline{3} \mathrm{~B}$ and $\mathrm{C}$, respectively). Contributions from the uranyl $v_{\mathrm{as}}\left(\mathrm{U}-\mathrm{O}_{\mathrm{ax}}\right)$ modes were observed at $\tilde{\nu}$ $=908$ and $912 \mathrm{~cm}^{-1}$ (Figures S2 C and D in the Supporting Information, that is, at frequencies similar to those reported previously for the CaM1P-U complexes of Pardoux et al.3c). As previously discussed, negative bands at $\tilde{\nu}=1570-1580,1399-1401,1419-1421 \mathrm{~cm}^{-1}$ clearly correspond to the $v_{\text {as }}\left(\mathrm{COO}^{-}\right)$and $v_{\mathrm{s}}\left(\mathrm{COO}^{-}\right)$modes of aspartate(s) and glutamate groups in CaM1P, which are affected by the coordination of uranyl ions.

Differences in the frequency of these modes for CaM1P and CaM1 suggest either that the phosphorylation of threonine $\mathrm{T} 9$ slightly modifies the interactions formed by the carboxylate side chains with their environment or that different aspartate groups are involved in the uranyl coordination in the CaM1-U and CaM1P-U complexes. The structural models obtained by MD simulations indeed propose that Asp1 is involved in uranyl coordination only in the CaM1P-U complex formed with the deprotonated phosphoryl group whereas Asp3 is involved in uranyl complexation in the other complexes (Table 2). Negative bands at $\tilde{\nu}=1655$ and $1546 \mathrm{~cm}^{-1}$ at pH 6 and at $\tilde{\nu}=1548 \mathrm{~cm}^{-1}$ at $\mathrm{pH} 7$ are specific of the spectra recorded with CaM1P. They are characteristic for the amide I and amide II modes, that is, contributions of peptide bond(s), and again suggest a different reorganization of the metal binding loop upon uranyl coordination in the phosphorylated and non-phosphorylated peptides. As discussed previously for the CaM1U complex, positive bands at $\tilde{\nu}=1521-1522$ and $1455-1456 \mathrm{~cm}^{-1}$ in the spectra of the CaM1P$\mathrm{U}$ complexes formed at pH 6 and 7 clearly correspond to a bidentate carboxylate coordination, whereas the positive band at $\tilde{\nu}=1616-1617 \mathrm{~cm}^{-1}$ corresponds to a typical monodentate carboxylate ligand. Another positive band at $\tilde{\nu}=1674 \mathrm{~cm}^{-1}$ at $\mathrm{pH} 6$ and at $\tilde{\nu}=1668 \mathrm{~cm}^{-1}$ at $\mathrm{pH}$ 7 could either correspond to a monodentate carboxylate or to a carbonyl group. In this region, there are differences between spectra recorded at $\mathrm{pH} 6$ and 7: the negative amide I band 
at $\tilde{\nu}=1655 \mathrm{~cm}^{-1}$ at $\mathrm{pH} 6$ is not observed in the CaM1P-U-minus-CaM1P spectrum recorded at $\mathrm{pH} 7$, most probably because of the superimposition of a positive band present at approximately $\tilde{\nu}=1650 \mathrm{~cm}^{-1}$ only at $\mathrm{pH}$. This band could also correspond to a carbonyl group or to a monodentate carboxylate ligand. These differences either point to the involvement of different carboxylate groups in a monodentate uranyl coordination at $\mathrm{pH} 6$ and 7 or a different environment of the carboxylate groups involved in the uranyl coordination at $\mathrm{pH} 6$ and 7 in the CaM1P-U complex. In line with this interpretation, a positive band also appears at approximately $\tilde{\nu}=1710 \mathrm{~cm}^{-1}$ notably at $\mathrm{pH}$, in the region are protonated carboxylic groups are expected to contribute. This band suggests that the structure of the CaM1P-U complex stabilizes a protonated carboxylic acid not involved in the uranyl coordination at $\mathrm{pH} 6$, probably through hydrogen-bonding interaction.

We conclude from the FTIR experiments that aspartate(s) and the glutamate of the metal binding loop are involved in uranyl binding and that at least one bidentate and one monodentate carboxylate ligand are present in all the uranyl complexes formed by CaM1P or CaM1. We also conclude that a carbonyl group could participate to uranyl coordination in the CaM1-U complex. These data are in line with the MD structural models except for that with a bidentate phosphoryl ligand (Table 2).

\section{EXAFS}

The EXAFS spectra obtained with two different samples corresponding to the CaM1P-U complex formed at pH 6 are almost superimposable (data not shown). In addition, similar EXAFS spectra were obtained with the CaM1-U complexes at peptide/uranyl ratios of 1:1 and 1:0.5, which is a good indication that a unique uranyl binding site is probed under the experimental conditions used for EXAFS. After the EXAFS measurements, the samples were analyzed by using electrospray ionization mass spectrometry (ESI MS) to identify any degradation of the peptides due to the synchrotron X-rays as detailed in Figure S3 in the Supporting Information. None of the peptide samples were degraded after exposure to the Xray beam and the phosphoryl group was conserved in all the phosphorylated peptides.

\section{CaM1P-U complex}

The $k^{3}$-weighted EXAFS spectra of the CaM1P-U complexes formed at $\mathrm{pH} 6$ and 7 are presented in Figure $\underline{4}$ along with the corresponding Fourier transforms (FT). The best fits obtained from the fitting procedure are shown as red curves. The FT represents a pseudo-radial distribution function of the uranium near-neighbor environment. The peaks appear at lower $R$ values relative to the true near-neighbor distances as a result of the EXAFS phase shift, which is different for each neighboring atom ( $\phi=0.2$ to $0.5 \AA$ ). Solely on the basis of the raw data, the spectra of the CaM1P-U complexes at pH 6 and 7 show a strong similarity. 

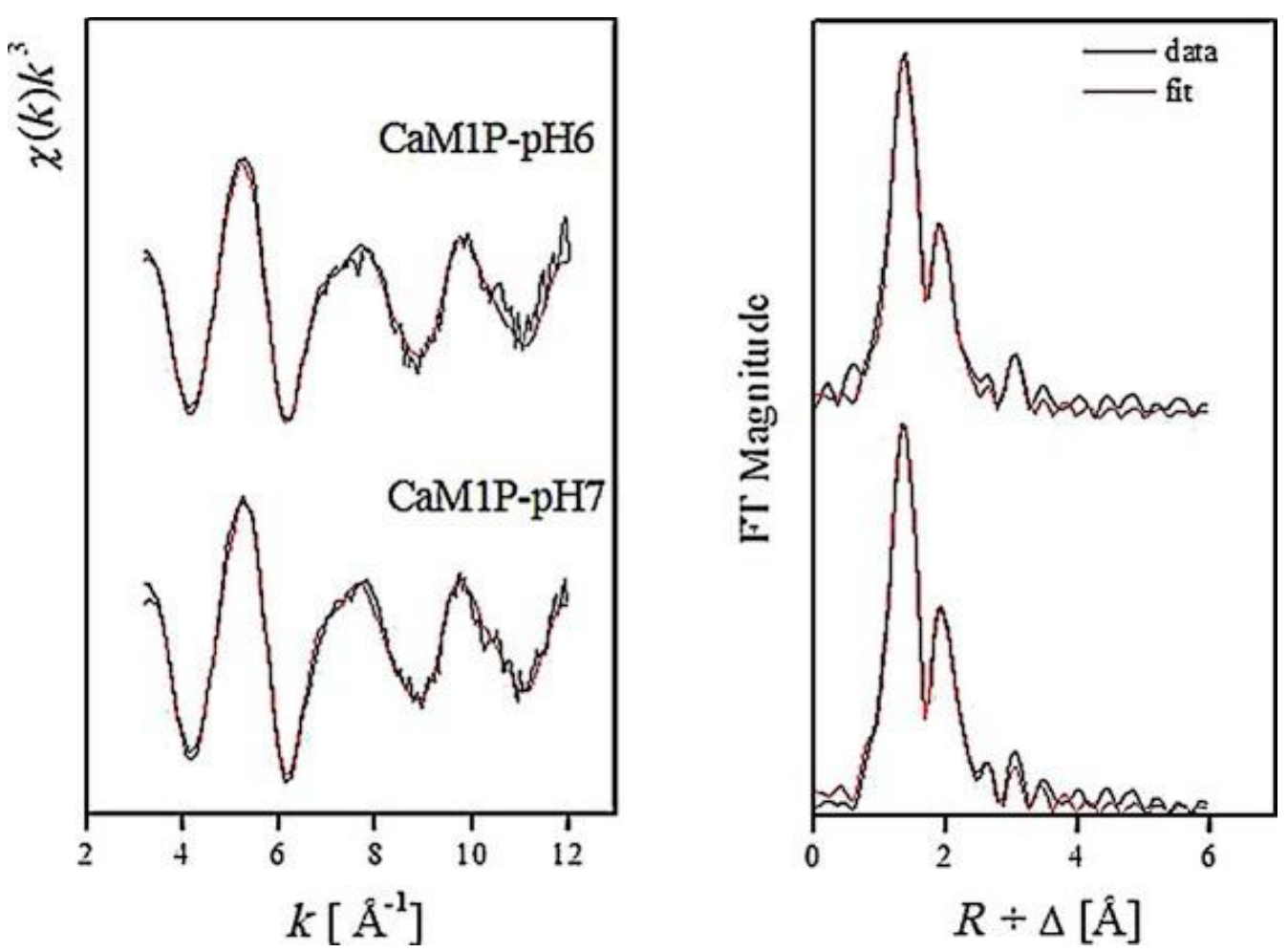

\section{Figure 3}

$U L_{\text {III }}$ edge $k^{3}$-weighted EXAFS spectra (left) and the corresponding Fourier transforms (right) of the CaM1P-U complexes formed at pH 6 (upper traces) and 7 (lower traces). The experimental spectra are given in black and the fits are given in red.

There is a close agreement among the two samples in the phases as well as in the amplitude of all the features in the $k$ space. Similarly, the $R$ space plots of the Fourier-transformed EXAFS spectra are also in close agreement. This indicates that the local coordination of $U$ in the CaM1P-U complexes is very similar at $\mathrm{pH} 6$ and 7.

Three different geometrical configurations were tested by computer simulation to fit the EXAFS spectral data of the CaM1P-U complex: scenarios in which 1) the phosphoryl group does not participate in the uranyl coordination, 2) the phosphoryl group is involved as a uranyl bidentate ligand, and 3) the phosphoryl group is involved as an uranyl monodentate ligand, which is in line with the different structural models obtained by using MD simulations. The structural parameters resulting from the final best fits of the spectra are summarized in Table $\underline{3}$.

Table 3. Structural parameters of the CaM1P-U complexes formed at $p H 6$ and 7.

\begin{tabular}{|c|c|c|c|c|c|}
\hline Sample & Shell & $N^{\text {[a] }}$ & $R[\AA]^{[b]}$ & $\boldsymbol{\sigma}^{2}\left[\AA^{2}\right]^{[\mathrm{cc}]}$ & $\Delta E[\mathrm{eV}]$ \\
\hline CaM1P & $\mathrm{U}-\mathrm{O}_{\mathrm{ax}}$ & $2.0^{[\mathrm{d}]}$ & 1.77 & 0.0041 & 1.35 \\
\hline \multirow[t]{2}{*}{ pH 6} & $\mathrm{U}-\mathrm{O}_{\mathrm{eq}} 1$ & $3.0^{[\mathrm{d}]}$ & 2.32 & 0.0079 & \\
\hline & $\mathrm{U}-\mathrm{O}_{\text {еq }} 2$ & $2.0^{[\mathrm{d}]}$ & 2.48 & 0.0050 & \\
\hline
\end{tabular}




\begin{tabular}{|c|c|c|c|c|c|}
\hline Sample & Shell & $N^{[a]}$ & $R[\AA]^{[\mathbf{b}]}$ & $\sigma^{2}\left[\AA^{2}\right]^{[\mathrm{c}]}$ & $\Delta E[\mathrm{eV}]$ \\
\hline & $\mathrm{U}-\mathrm{C} 1$ & $1.0^{[\mathrm{d}]}$ & 2.90 & $0.0038^{[\mathrm{d}]}$ & \\
\hline & $\mathrm{U}-\mathrm{C} 2$ & $2.0^{[\mathrm{d}]}$ & 3.46 & $0.0038^{[\mathrm{d}]}$ & \\
\hline & $\mathrm{U}-\mathrm{P}$ & $1.0^{[\mathrm{d}]}$ & 3.69 & $0.014^{[\mathrm{d}]}$ & \\
\hline & $\mathrm{U}-\mathrm{O}_{\mathrm{eq}} 1-\mathrm{P}(\mathrm{MS})$ & $2.0^{[e]}$ & $3.80^{[\mathrm{f}]}$ & $0.014^{[\mathrm{d}]}$ & \\
\hline CaM1P & $\mathrm{U}-\mathrm{O}_{\mathrm{ax}}$ & $2.0^{[\mathrm{d}]}$ & 1.78 & 0.0041 & 2.24 \\
\hline \multirow[t]{6}{*}{ pH 7} & $\mathrm{U}-\mathrm{O}_{\mathrm{eq}} 1$ & $3.0^{[\mathrm{d}]}$ & 2.32 & 0.011 & \\
\hline & $\mathrm{U}-\mathrm{O}_{\mathrm{eq}} 2$ & $2.0^{[\mathrm{d}]}$ & 2.48 & 0.0078 & \\
\hline & $\mathrm{U}-\mathrm{C} 1$ & $1.0^{[\mathrm{d}]}$ & 2.89 & $0.0038^{[\mathrm{d}]}$ & \\
\hline & $\mathrm{U}-\mathrm{C} 2$ & $2.0^{[\mathrm{d}]}$ & 3.44 & $0.0038^{\text {[d] }}$ & \\
\hline & $\mathrm{U}-\mathrm{P}$ & $1.0^{[\mathrm{d}]}$ & 3.65 & $0.0012^{[\mathrm{d}]}$ & \\
\hline & $\mathrm{U}-\mathrm{O}_{\mathrm{eq}} 1-\mathrm{P}(\mathrm{MS})$ & $2.0^{[\mathrm{ee}]}$ & $3.75^{[\mathrm{f}]}$ & $0.0012^{[\mathrm{d}]}$ & \\
\hline
\end{tabular}

- [a] Errors in the coordination numbers are $\pm 25 \%$. [b] Errors in the distances are $\pm 0.02 \AA$. [c] Debye-Waller factor. [d] Parameter fixed for calculation. [e] Coordination number (N) linked twice to $N$ of the $U-P$ path. [f] Parameter linked by proportionality to the parameter in the row above.

In samples at pH 6 and 7, fitting shows that $\mathrm{U}^{\mathrm{vi}}$ has two $\mathrm{O}_{\mathrm{ax}}$ atoms at a distance of $(1.77 \pm 0.02)-$ $(1.78 \pm 0.02) \AA$ and five $\mathrm{O}_{\text {eq }}$ atoms at $(2.39 \pm 0.02) \AA$. The high Debye-Waller factor of the $\mathrm{U}-\mathrm{O}_{\text {eq }}$ shell $\left(0.015 \AA^{2}\right)$ obtained in this preliminary fit (not shown) corresponds to a high disorder at this shell, indicating the presence of different geometrical distances of the neighboring groups. The splitting of this shell into two components was possible because the resolution, as given by $\Delta R \geq \pi /\left(2 k_{\max }\right)$ was approximately $0.3 \AA .21$ The $\mathrm{U}-\mathrm{O}_{\text {eq }}$ shell was split into 
two components, with the first component $\left(\mathrm{U}-\mathrm{O}_{\mathrm{eq}} 1\right)$ at a distance of $(2.32 \pm 0.02) \AA$ and the second component $\left(\mathrm{U}-\mathrm{O}_{\mathrm{eq}} 2\right)$ at a somewhat longer distance (i.e., $(2.48 \pm 0.02) \AA$ ). The $\mathrm{U}-\mathrm{O}_{\mathrm{eq}} 1$ bond lengths are within the range of previously reported values for the oxygen atom of phosphate and/or carboxylate groups bound to uranyl in a monodentate fashion. $\underline{3 \mathrm{e}}, \underline{7 \mathrm{~b}}, \underline{22}$ The longer equatorial oxygen bond length (i.e., $(2.48 \pm 0.02) \AA$ ) is similar to previously reported values for the oxygen atom of carboxylate groups bound to uranyl in a bidentate mode (2.45$2.51 \AA$ ). 23 These two shells of $\mathrm{O}_{\mathrm{eq}}$ atoms thus could correspond to the presence of monodentate and bidentate carboxylate ligands, as deduced from the FTIR data. The best fit was obtained with a coordination number of three for the $\mathrm{U}-\mathrm{O}_{\mathrm{eq}} 1$ bond and two for $\mathrm{U}-\mathrm{O}_{\mathrm{eq}} 2$ bond, which is in accordance with the presence of a bidentate carboxylate ligand together with two monodentate carboxylate groups and monodentate binding of the phosphothreonine.

The other FT components were fitted with two carbon shells, that is, C1 at 2.89-2.90 $\AA$ and C2 at 3.44-3.46 $\AA$, the contribution of U-P at 3.65-3.69 $\AA$, and multiple-scattering $U-\mathrm{O}_{\text {eq }} 1-\mathrm{P}$ at $3.75-3.8 \AA$. The $\mathrm{U}-\mathrm{C} 1$ bond length of $2.89-2.90 \AA$ is consistent with a coordination of Uvi to a bidentate carboxyl group. This distance has been described for the bidentate coordination of carbonate to uranyl and actinyl complexes. $7 \mathrm{~b}, \underline{23}, \underline{24}$ The $\mathrm{U}-\mathrm{C} 2$ bond length is typical for a monodentate coordination of $U^{v i}$ by carboxylate groups. The U-P distance of 3.65-3.69 $\AA$ is consistent with a monodentate coordination of the phosphoryl group to the uranyl equatorial plane as it was found in lipopolysaccharides $\underline{7 \mathrm{a}}$ or osteopontin, $\underline{\mathrm{ze}}$ and with a monodentate phosphate coordination in meta-autunite. $7 \mathrm{~b}$ This topology is common in crystalline uranyl phosphates and was reported for $\mathrm{U}^{\mathrm{vI}}$ sorbed at bacterial cell surfaces. $22, \underline{24}$

EXAFS data collected for the CaM1P-U complexes at pH 6 and 7 are consistent with a uranyl fivefold coordination involving one bidentate and two monodentate carboxylate ligands, in addition to one monodentate phosphoryl ligand. These experimental data are in line with the FTIR data and with model A of Figure 2 , issuing from the MD simulations, in which the coordination sphere of uranyl consists of the monodentate Asp1 and Glu12, the bidentate Asp5, and the monodentate phosphothreonine9. The flexibility of the uranyl coordination sphere was observed by the MD simulations, with the possible involvement of a main-chain carbonyl group from Tyr7. Suzuki et al.25 reported $\mathrm{U}-\mathrm{O}_{\mathrm{eq}}$ bond lengths ranging from 2.31 to $2.41 \AA$ for the $\mathrm{U}-\mathrm{O}(\mathrm{C}=\mathrm{O})$ shell. The corresponding $\mathrm{U}-\mathrm{C}$ bond length for a carbonyl ligand would contribute around $3.5 \AA$. These $\mathrm{U}-\mathrm{O}_{\mathrm{eq}}$ and $\mathrm{U}-\mathrm{C}$ bond lengths are thus comparable to the experimental $\mathrm{U}-\mathrm{O}_{\mathrm{eq}} 1$ and $\mathrm{U}-\mathrm{C} 2$ bond lengths obtained in this work. Therefore, we may not discriminate between the binding of a monodentate carboxylate and that of a carbonyl group in the uranyl coordination sphere of the CaM1P-U complex.

\section{CaM1-U complex}

The $k^{3}$-weighted EXAFS spectrum of the uranium species formed by the non-phosphorylated CaM1 and its corresponding FT are presented as black lines in Figure $\underline{5}$ and the best fits obtained from the fitting procedure with two different models (see below) are shown as red curves. The FT of the EXAFS spectrum of this sample shows five significant peaks. The 
quantitative fit results (Table $\underline{4}$, distances are phase shift corrected) indicate that the bound $\mathrm{U}^{\mathrm{VI}}$ has the common linear trans-dioxo structure with two axial oxygen atoms at about (1.77 \pm 0.02$) \AA$ with an average Debye-Waller factor $\left(\sigma^{2}\right)$ of $0.0036 \AA^{2}$. The EXAFS spectrum of this sample contains a second shell with an average bond length of (2.38 \pm 0.02$) \AA$ and a Debye-Waller factor of 0.0141-0.0163 $\AA^{2}$. The coordination number for this shell, as obtained in a preliminary fit (not shown) is $(5.3 \pm 0.7)$, and does not allow discriminating between a fivefold or a six-fold uranyl coordination (see Table S2 in the Supporting Information for a comparison of five and six $\mathrm{U}-\mathrm{O}_{\mathrm{eq}}$ coordination). The value of the Debye-Waller factor of the $\mathrm{U}-\mathrm{O}_{\text {eq }}$ shell was high and the $\mathrm{U}-\mathrm{O}_{\text {eq }}$ shell was split into two components, a first component $\left(\mathrm{U}-\mathrm{O}_{\mathrm{eq}} 1\right)$ at a very short distance of $(2.20 \pm 0.02) \AA$ and a second component $\left(\mathrm{U}-\mathrm{O}_{\mathrm{eq}} 2\right)$ at a distance of $(2.37 \pm 0.02) \AA$. The short $\mathrm{U}-\mathrm{O}_{\mathrm{eq}} 1$ bond length may indicate very strong interaction with a monodentate carboxylate group in the CaM1-U complex. It is however shorter than usual $\mathrm{U}-\mathrm{O}_{\mathrm{eq}}$ bond lengths for monodentate carboxylate ligands, described to be ranging from $(2.26 \pm 0.02)$ to $(2.36 \pm 0.02) \AA . \underline{7 b}, \underline{23}, \underline{26}$

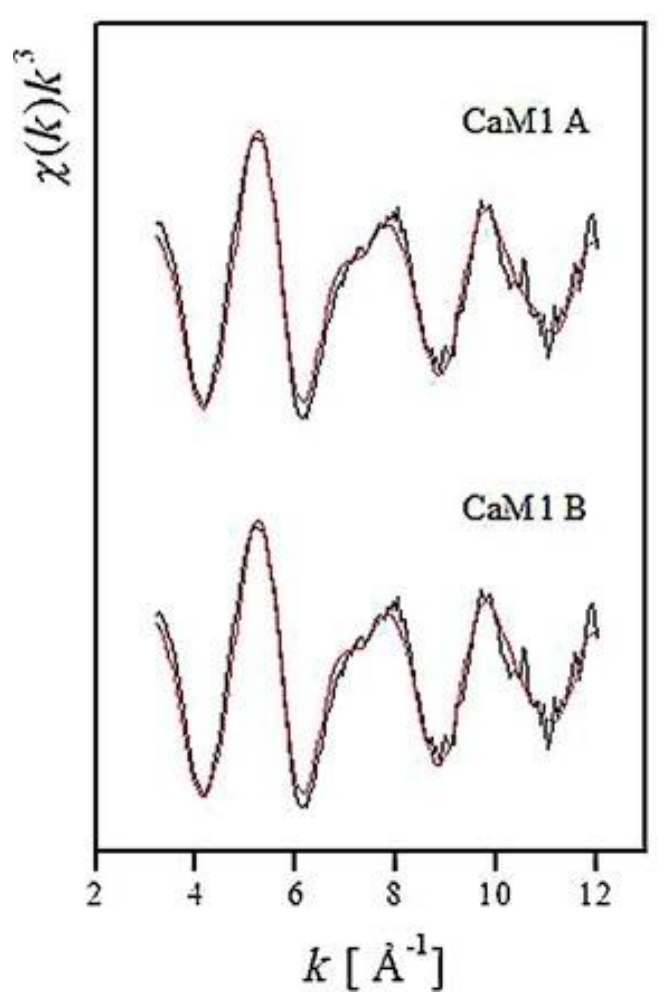

\section{Figure 4}

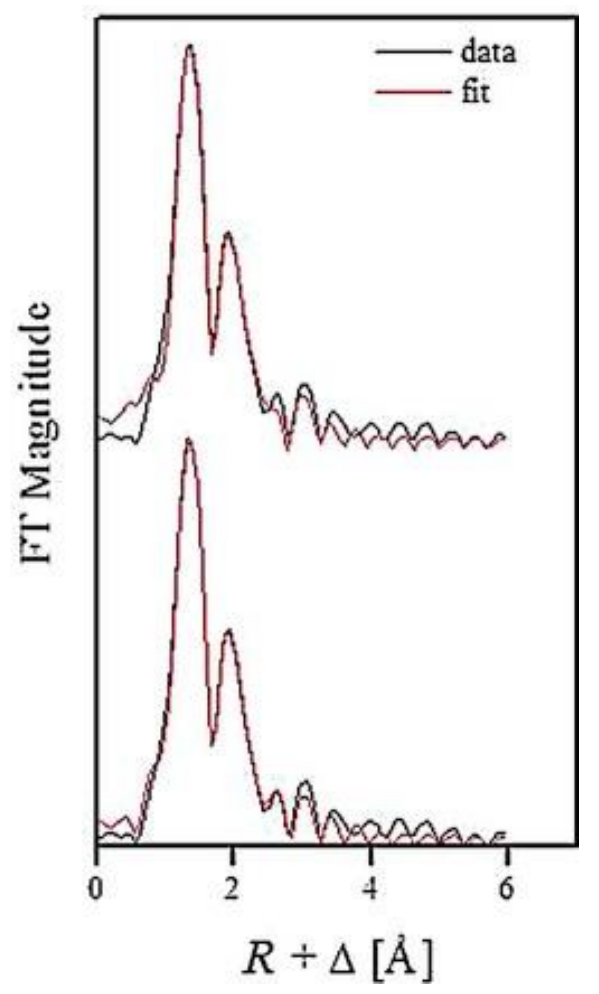

$U L_{I I I}$ edge $k^{3}$-weighted EXAFS spectra (left) and the corresponding Fourier transforms (right) of the CaM1-U complex at pH6. The coordination number of C1 was fixed to one, corresponding to a scenario where $U$ is coordinated to one bidentate carboxylate group. For the $U-C 2$ shell, two models were taken into consideration, that is, model A and model B where two or three carbon atoms were included in the fit, respectively, to take into account a model with a hydroxide uranyl ligand or a model with exclusively protein ligands from monodentate carboxylate or carbonyl oxygen atoms. The experimental signals are given in black, the fits are given in red. 
Table 4. Structural parameters of the CaM1-U complex formed at $\mathrm{pH} 6$.

\begin{tabular}{|c|c|c|c|c|c|c|}
\hline Sample & Shell & $N^{\text {[a] }}$ & $R[\AA]^{[\mathbf{b}]}$ & $\boldsymbol{\sigma}^{2}\left[\AA^{2}\right]^{[\mathrm{c}]}$ & $\Delta E[\mathrm{eV}]$ & Error $^{[e]}$ \\
\hline \multirow[t]{6}{*}{ model A } & $\mathrm{U}-\mathrm{O}_{\mathrm{ax}}$ & $2.0^{[\mathrm{d}]}$ & 1.77 & 0.0036 & -4.66 & 0.179 \\
\hline & $\mathrm{U}-\mathrm{O}_{\mathrm{eq}} 1$ & $1.0^{[\mathrm{d}]}$ & 2.20 & 0.0036 & & \\
\hline & $\mathrm{U}-\mathrm{O}_{\mathrm{eq}} 2$ & $4.0^{[\mathrm{d}]}$ & 2.37 & 0.0077 & & \\
\hline & $\mathrm{U}-\mathrm{O}_{\mathrm{eq}} 3$ & $1.0^{[\mathrm{d}]}$ & 2.84 & 0.0034 & & \\
\hline & $\mathrm{U}-\mathrm{C}_{1}$ & $1.0^{[\mathrm{d}]}$ & 2.86 & 0.002 & & \\
\hline & $\mathrm{U}-\mathrm{C} 2$ & $2.0^{[\mathrm{d}]}$ & 3.41 & 0.0039 & & \\
\hline \multirow[t]{6}{*}{ model B } & $\mathrm{U}-\mathrm{O}_{\mathrm{ax}}$ & $2.0^{[\mathrm{dd}]}$ & 1.77 & 0.0036 & -4.53 & 0.186 \\
\hline & $\mathrm{U}-\mathrm{O}_{\mathrm{eq}} 1$ & $1.0^{[\mathrm{d}]}$ & 2.20 & 0.0036 & & \\
\hline & $\mathrm{U}-\mathrm{O}_{\mathrm{eq}} 2$ & $4.0^{[\mathrm{dd}]}$ & 2.37 & 0.0077 & & \\
\hline & $\mathrm{U}-\mathrm{O}_{\mathrm{eq}} 3$ & $1.0^{[\mathrm{d}]}$ & 2.85 & 0.0027 & & \\
\hline & $\mathrm{U}-\mathrm{C} 1$ & $1.0^{[\mathrm{d}]}$ & 2.85 & 0.0020 & & \\
\hline & $\mathrm{U}-\mathrm{C} 2$ & $3.0^{[\mathrm{d}]}$ & 3.40 & 0.0076 & & \\
\hline
\end{tabular}

- [a] Errors in the coordination numbers are $\pm 25 \%$. [b] Errors in the distance are $\pm 0.02 \AA$. [c] Debye-Waller factor. [d] Value fixed for calculation. [e] The error is given as the normalized fit error $\sum\left(\chi d a t a(k) k^{3}-\chi f i t(k) k^{3}\right)^{2} /(P-F)(P=$ number of data points, $F=$ number of variables $)$.

Alternately, this short distance could indicate the presence of another type of ligand, as a hydroxide ligand.27 Actually, previous EXAFS analysis of the uranyl complex formed at $\mathrm{pH} 7$ with the CaMWT peptide, which presents high sequence similarity with CaM1 (Table S1 in the Supporting Information) concluded to the presence of a hydroxide uranyl ligand. $\underline{3 f}$ 
Inspection of uranyl complexes of known structures showed that the presence of such a short uranyl-ligand distance was only observed in five-coordinated uranyl ligands and thus excluded the hypothesis of a six-coordinated CaM1-U complex. $\underline{3 \mathrm{~d}} \mathrm{We}$ fitted the EXAFS data accordingly by using four oxygen atoms in the $\mathrm{U}-\mathrm{O}_{\mathrm{eq}} 2$ layer (Table $\underline{4}$ ). We observed that two shells of carbon atoms, scattering at distances of $(2.86 \pm 0.02)$ and (3.40 \pm 0.02$) \AA$, improved the fit significantly. These distances are typical for bidentate and monodentate coordination of $\mathrm{U}^{\mathrm{vi}}$ by carboxylate groups, respectively. $\underline{7 \mathrm{~b}}, \underline{23}$ The coordination number of $\mathrm{C} 1$ was fixed to one corresponding to a scenario where $U$ is coordinated to one bidentate carboxylate group. For the $\mathrm{U}-\mathrm{C} 2$ shell, two models were taken in consideration, that is, model A and model B where two or three carbon atoms were included in the fit, respectively, to take into account a model with a hydroxide uranyl ligand or a model with exclusively protein ligands from monodentate carboxylate or carbonyl oxygen atoms. No significant differences were obtained between these two models in term of the $R$ factor (Table $\underline{4}$ ) indicating that EXAFS spectroscopy could not differentiate between the implications of two monodentate carboxylate ligands in the uranyl coordination or the implication of two monodentate ligands in addition to another ligand with a short $\mathrm{U}-\mathrm{O}_{\mathrm{eq}}$ distance, as expected for a hydroxide group.

The addition of an oxygen shell at a distance of $R=(2.84 \pm 0.02) \AA$ significantly improved the fit for these two models (Table 4 ). This additional atom is not related to direct bonding to uranyl, but a similar behavior has been previously interpreted as scattering contributions from neighboring ligand shells known as short contacts in crystallography. $\underline{7 b}, \underline{28}$ It is in accordance with the MD simulations showing the presence of carboxylate oxygen atoms at the proximity of uranium in the structural models.

The conclusions from the EXAFS experiments for the phosphorylated peptides at $\mathrm{pH} 6$ and 7 are in agreement with a structural model involving three short $\mathrm{U}-\mathrm{O}_{\text {eq }}$ distances and two longer $\mathrm{U}-\mathrm{O}_{\mathrm{eq}}$ distances, which could correspond to the presence of a monodentate phosphoryl group and two monodentate and one bidentate carboxylate ligands, which is in agreement with the FTIR data and the MD simulations. For the CaM1-U complex, the EXAFS data evidenced a short $\mathrm{U}-\mathrm{O}_{\mathrm{eq}}$ distance of approximately $2.2 \AA$, which was similar to that observed for the CaMWT-U complex.3f Distinction between the contribution at the uranyl-oxygen distance of approximately 2,2 $\AA$ of either a monodentate carboxylate with strong interaction with the uranyl or that of a hydroxide ligand is however difficult by solely using the EXAFS data.

Therefore, we further probed the uranyl coordination in the CaM1-U complex by using TRLFS. TRLFS is very sensitive to the uranyl speciation and in particular to discriminate hydroxide or aquo ligands in the uranyl equatorial coordination sphere.29

\section{TRLFS}

Uranyl speciation was studied in solution by following the fluorescence spectra for the Uvions (at $\left.4.10^{-5} \mathrm{M}\right)$ in the presence of CaM1 $\left(1.10^{-4} \mathrm{M}\right)$ and 2-(N-morpholino)ethanesulfonic acid (MES) buffer $(2 \mathrm{mM})$ at various $\mathrm{pH}$ values ranging from $\mathrm{pH} 3$ to 7 . The uranyl and CaM1 
concentrations remained constant during the whole experiment and the $\mathrm{pH}$ value was the only variable parameter. The obtained spectra are shown in Figure $\underline{6}$.

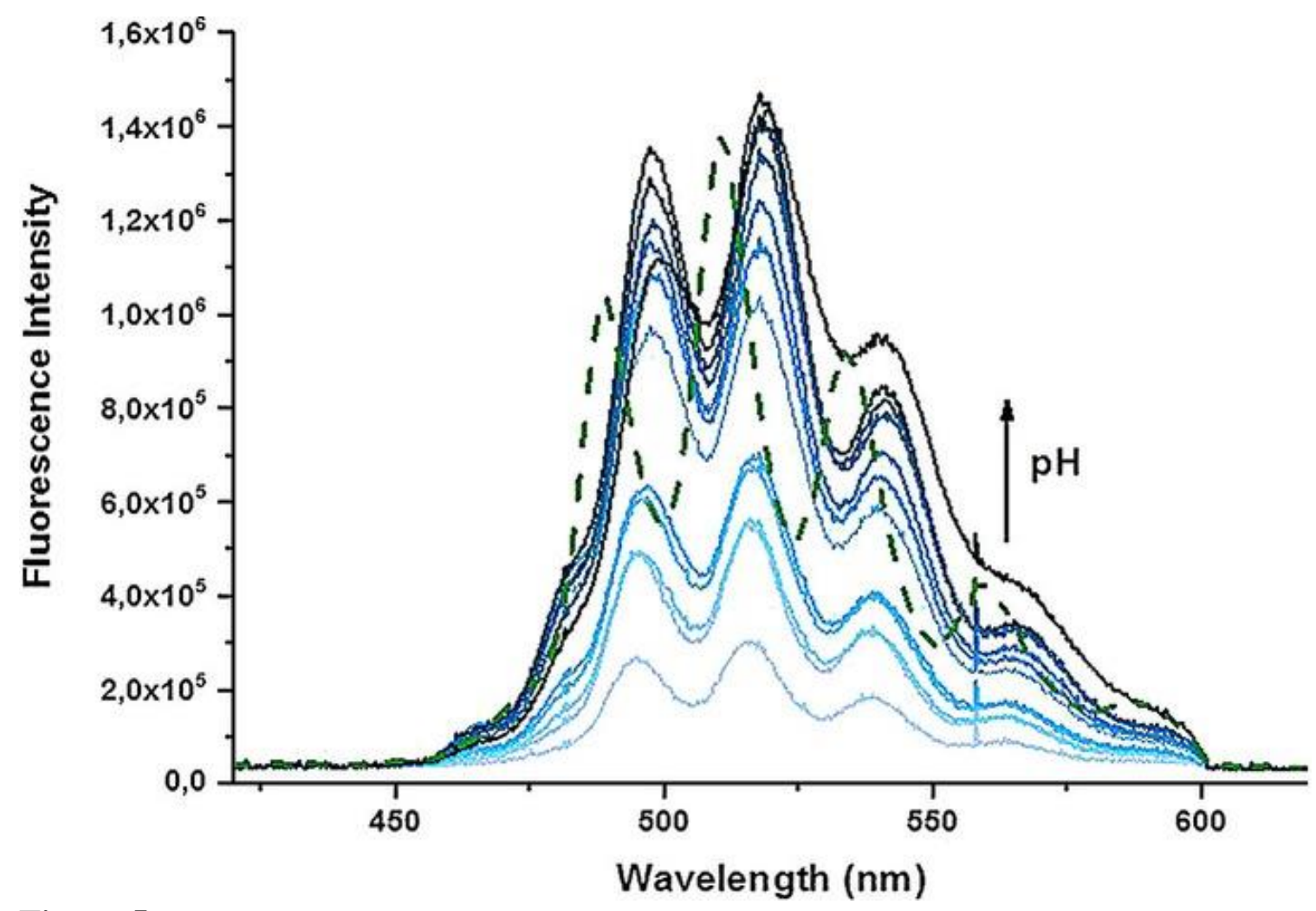

Figure 5

Fluorescence spectra of uranyl in a solution containing CaMI at different $\mathrm{pH}$ values, from pH 3 to 7 (blue lines) compared to the fluorescence spectrum of free uranyl recorded at $\mathrm{pH} 3$ (green dotted line).

A $5 \mathrm{~nm}$ redshift of the uranyl fluorescence spectrum and a diminution of the fluorescence intensity are observed upon addition of CaM1 to the uranyl solution at $\mathrm{pH} 3$ (Figure $\underline{6}$ ). This suggests that a CaM1-U complex is readily formed upon addition of the peptide to the uranyl solution. The $\mathrm{pH}$ value of the solution was then progressively increased to 7 . The intensity of the fluorescence spectrum increased along with the $\mathrm{pH}$ value until $\mathrm{pH} 5.6$ was reached. A progressive $3 \mathrm{~nm}$ redshift of the spectrum was observed between $\mathrm{pH} 3$ and 6.3, meaning either that the fraction of uranium bound to the peptide increases with an increase of the $\mathrm{pH}$ value or that another uranyl complex forms with an increasing proportion upon an increase of the $\mathrm{pH}$ value. At $\mathrm{pH} 7$, the spectrum changes and becomes typical for an uranyl-hydrolyzed species.29c This indicates a dominating concentration of uranyl-hydroxide complexes, as compared to the concentration of CaM1-U complexes, which is confirmed by the analysis of the fluorescence lifetimes (Table $\underline{5}$, Figure $\underline{7}$ ).

Table 5. Attribution of the lifetimes to the related species. 


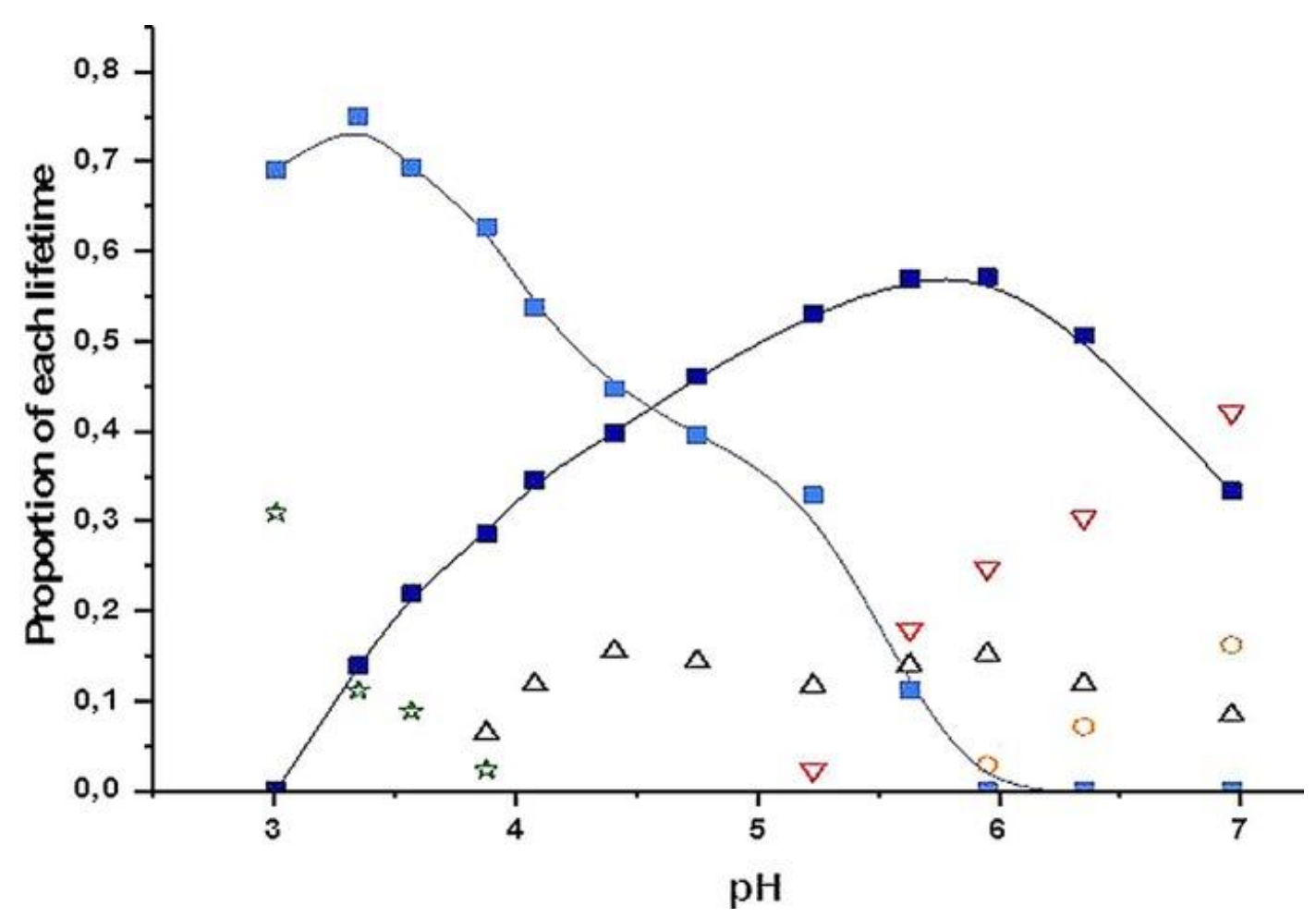

\section{Figure 6}

Evolution of the proportion of the uranyl fluorescence lifetimes as a function of the $\mathrm{pH}$ value [0.4 (light blue squares), 1 (red triangles), 2 (green stars), 4 (dark blue squares), 7 (orange circles), and $24 \mu$ s (black triangles)].

Kinetics analysis of the fluorescence lifetimes shows a bi-exponential decay at $\mathrm{pH} 3$ (Figure $\underline{7}$ ). Between pH 3 and 5, the fluorescence kinetics could be fitted with a three-exponential decay, whereas four-exponential decays were identified at $\mathrm{pH}$ values higher than 5 (Figure S4 in the Supporting Information). These data indicated the presence of mixtures of at least two, three, 
or four uranyl species at the different $\mathrm{pH}$ values. Kinetics analysis evidences six different lifetimes with $0.4,1,2,4,7$, and $24 \mu \mathrm{s}$. The lifetime contribution of $2 \mu \mathrm{s}$, typical of a free $\mathrm{Uvi}^{\mathrm{vI}}$ aquo ion, is present only at low pH (Table $\underline{529 \mathrm{~b}}$ ). The contribution of the $24 \mu$ s lifetime appears at $\mathrm{pH} 3.9$ and is present in a small and constant amount in the $\mathrm{pH}$ range from 4 to 7 (Figure 7). It can be assigned to the $\left(\mathrm{UO}_{2}\right)_{2}(\mathrm{OH})_{2}{ }^{2+}$ species, by comparison with literature data.29b The quantum yield of this species being 80 times higher than that of the free uranyl,29a we could detect it even though its concentration in solution was close to zero. The 1 $\mu$ s lifetime appears at $\mathrm{pH}$ greater than 5 and its proportion increases with the $\mathrm{pH}$. This lifetime was assigned to another hydroxide species, most likely $\mathrm{UO}_{2}(\mathrm{OH})_{3}{ }^{-}$, according to the speciation diagram of uranyl at this concentration. $29 \mathrm{~d}$ The fluorescence efficiency of that species is four times higher than that of the free uranyl as well,29a which explains why it contributes significantly to the kinetic traces even though its concentration is relatively limited in solution at $\mathrm{pH}$ values below 7. Moreover, the spectrum calculated for that species (Figure S6 in the Supporting Information) matches quite well the spectrum found in the literature.29d

The shortest lifetime (i.e., $0.4 \mu \mathrm{s}$ ) is assigned to a CaM1-U complex, as it is the dominating kinetic component at $\mathrm{pH} \mathrm{3}$, and as stated before, the redshift of the fluorescence spectrum upon addition of the peptide at $\mathrm{pH} 3$ indicates an immediate complexation of the uranyl ion by the peptide at this $\mathrm{pH}$ value. Complexation of uranyl by CaM1 thus leads to a decrease in the uranyl fluorescence lifetime, which is in agreement with literature data, because short fluorescence lifetimes were reported for uranyl complexes involving organic ligands. $\underline{30}$

The proportion of the CaM1-U complex (corresponding to the $0.4 \mu \mathrm{s}$ lifetime component) decreases with an increasing $\mathrm{pH}$ value. In parallel the contribution of another uranyl species characterized by a $4 \mu$ s fluorescence lifetime increases until $\mathrm{pH} 5.5$, remains stable until $\mathrm{pH}$ 6.5, and then drops at $\mathrm{pH} 7$ (Figure 7). We assign this contribution to another form of the CaM1-U complex, in which the uranyl ion is hydrolyzed, by comparison with literature data showing that participation of hydroxide group(s) to uranyl coordination increases the fluorescence lifetime of the uranyl species.29a, 29c Increasing proportion of the $4 \mu$ s lifetime component with the $\mathrm{pH}$ is also fully compatible with the involvement of a hydroxide group in the uranyl coordination in this complex. This complex is believed to have the following structure: $\mathrm{CaM} 1\left[\mathrm{UO}_{2} \mathrm{OH}^{+}\right]$, which could explain the presence of the short $\mathrm{U}-\mathrm{O}_{\text {eq }}$ distance evidenced by EXAFS as the $\mathrm{U}-\mathrm{OH}$ distance, as reported in the literature. $27 \mathrm{~b}, 27 \mathrm{c}, \underline{31}$ Above $\mathrm{pH}$ 6.5, the proportion of uranyl complexed to CaM1 decreases whereas uranyl ions are present as polymerized hydroxides complexes ( $7 \mu$ s lifetime component). They become the dominating uranyl species above $\mathrm{pH} 7$.

In conclusion, the fluorescence data thus support the view that the short $\mathrm{U}-\mathrm{O}_{\mathrm{eq}}$ distance deduced from the EXAFS spectral analysis could correspond to the binding of a hydroxide group to the uranyl molecule in the CaM1-U complex. 
The different fluorescence spectra obtained during this study were used to calculate apparent stability constants for the two complexes with the Hypspec software $\underline{32}$ (Table $\underline{6}$, Figures S5S7 in the Supporting Information). The relevant hydrolysis constants of the uranyl ion were found in the literature (Table S3 in the Supporting Information).22, 29a The $\mathrm{p} K_{\mathrm{a}}$ value of 2.5 of the coordinating amino acids (i.e., aspartic acid and glutamic acid) were taken from the literature for isolated groups in solution. 33 These different equilibria were plotted into the refinement model as well as the equilibria of the two CaM1-U complexes. The apparent stability constant of the first complex [i.e., CaM1- $\left(\mathrm{UO}_{2^{2+}}\right)$ ] has a value of $\log \beta=(6.0 \pm 0.2)$ $\left(20^{\circ} \mathrm{C}\right.$, Table $\left.\underline{6}\right)$. For the second complex present at $\mathrm{pH}$ 6, that is, $\mathrm{CaM} 1\left(\mathrm{UO}_{2} \mathrm{OH}^{+}\right)$, the reported value is $\log \beta=(7.1 \pm 0.3)\left(20^{\circ} \mathrm{C}\right.$, Table $\left.\underline{6}\right)$. This later value is smaller than that determined experimentally by following the fluorescence of Tyr7 upon uranyl addition. One source of discrepancy may reside in the $\mathrm{pKa}$ values of the coordinating aspartate and glutamate ligands, that are expected to differ in the protein as compared to solution, due to hydrogen-bonding and electrostatic interactions within the binding loop.

Table 6. Apparent stability constants of the calmodulin complexes deduced from the deconvolution of the fluorescence data.

\begin{tabular}{|c|c|} 
Equilibria & $\log \boldsymbol{\beta}$ \\
$\mathrm{CaM} 1+\mathrm{UO}_{2}{ }^{2+} \rightleftharpoons \mathrm{CaM} 1\left(\mathrm{UO}_{2}{ }^{2+}\right)$ & $6 \pm 0.2$ \\
$\mathrm{CaM} 1+\mathrm{UO}_{2}{ }^{2+}+\mathrm{H}_{2} \mathrm{O} \rightleftharpoons \mathrm{CaM} 1\left(\mathrm{UO}_{2} \mathrm{OH}^{+}\right)+\mathrm{H}^{+}$ & \\
& \\
\hline
\end{tabular}

\section{$\underline{\text { Conclusions }}$}

We obtained detailed experimental information on the structure of the uranyl complexes formed in solution and at neutral $\mathrm{pH}$, at site I of the $\mathrm{N}$-terminal domain of calmodulin. These data allow rationalizing the large increase of the uranyl affinity of a phosphorylated site I in CaM1P as compared to the non-phosphorylated one.

For the CaM1P-U complex, FTIR and EXAFS data converge to propose penta-coordination of uranyl involving the monodentate deprotonated phosphoryl, two monodentate, and one bidentate carboxylate ligands, as illustrated by the MD simulations presented in Figure $\underline{2}$ A.

The high stability of this CaM1P-U complex may be explained not only by direct binding of the strong phosphoryl ligand, but also by short coordinating distances, corresponding to strong interaction with carboxylate ligands from the protein.

Direct complexation of uranyl by monodentate phosphoryl groups was also deduced from vibrational and XAS analyses of uranyl complexes with phosphorylated peptides, $\underline{\mathrm{Be}}, \underline{4 \mathrm{~g}}, \underline{14}$ including complexes formed with phosphopeptides at lower $\mathrm{pH}$ that 
presented a modest affinity for uranyl.14 This may illustrate that although phosphoryl groups are strong uranyl ligands and incontestable uranyl targets in proteins, the chemical nature and coordination mode of all ligands in the uranyl coordination sphere play a significant role in determining the stability of the (phospho-)peptide-uranyl complexes.

Another important result of this study is that a hydroxide ligand most probably completes the coordination sphere of uranyl in the CaM1-U complexes, in addition to mono- and bidentate coordination by carboxylate groups. Uranyl coordination by a hydroxide ligand is strongly supported by the short $\mathrm{U}-\mathrm{O}_{\mathrm{eq}}$ distance evidenced by EXAFS and by the exploration of uranyl speciation by means of TRLFS. These data are in line with previous findings on the related CaMWT-U complex, for which EXAFS also evidenced a short $\mathrm{U}-\mathrm{O}_{\mathrm{eq}}$ distance. $\underline{3 \mathrm{fE}}$ Elucidation of the uranyl coordination in the CaM1-U complex could be obtained only thanks to the combination of multiple advanced techniques, such as FTIR spectroscopy, TRLFS, and EXAFS, because the simple MD simulations used here, although giving a relevant model for the CaM1P-U complexes, provide only models involving ligands that are included at the beginning of the simulation.

Coordination of uranyl by a (non-protein) hydroxide ligand may explain in part the lower stability of the complexes formed by calmodulin site I variants and uranyl as compared to CaM1P. MD analysis of the structure-property relationship in variants of the engineered "super-uranium binding protein" $\underline{\mathrm{c}}$ concluded on a link between the number of water molecules in the uranyl coordination sphere and the lesser affinity for uranyl.6a However, the presence of such ligands may also be a compromise in that they may result in less constrained binding sites and hence provide stability through entropic stabilization of the complex. In this regard, it is interesting to note that structural models proposed for the uranyl complexes formed with phosphopeptides mimicking osteopontin $\underline{3 \mathrm{e}}$ or the cyclic phosphorylated peptide pS3 with strong uranyl affinity in the study by Stark et al.4g contain not only strong monodentate carboxylate and phosphoryl ligands but also water molecule(s) in the uranyl coordination sphere.

Finally, this study confirms the important role of a phosphoryl ligand in the stability of uranylprotein interactions. By evidencing a hydroxide uranyl ligand in calmodulin site I, this study also highlights the possible role of less studied ligands as water or hydroxide ions in the stability of protein-uranyl complexes. These data set bases for a better understanding of uranyl binding site properties and for the optimization of uranium binding sites in EF-hand motifs by combining phosphorylation and site-directed mutations.

\section{Experimental Section}

\section{Chemicals and stock solutions}

MES or Tris buffer solutions (20 mM, pH 6 or 7, respectively) were prepared with analytical grade salt $(99.5 \%$, Sigma) dissolved in ultrapure water (18 M $\Omega$ ). The $\mathrm{pH}$ values of the solutions were measured with a $\mathrm{pH}$ electrode (IoLine, Shott Instruments) and a $\mathrm{pH}$ meter (Mettler 
Toledo); the electrode was calibrated with standard buffers. The $\mathrm{pH}$ values of the buffer solutions were adjusted with $\mathrm{NaOH}$ (10 M, Sigma) or $\mathrm{HCl}$ (37\%, Sigma).

\section{Protein expression and purification}

Expression, phosphorylation, and purification of the recombinant proteins were performed as previously described by Pardoux et al. $3 \underline{c}$ and are detailed in the Supporting Information. After purification steps, the proteins were dialyzed against MES (20 mM, pH 6) or Tris $(20 \mathrm{mM}, \mathrm{pH}$ 7). Protein samples were concentrated by using a Microcon filtration system (Amicon Millipore) with a cut-off point of $3 \mathrm{kDa}$.

Preparation of protein samples for $\mathrm{X}$-ray absorption spectroscopy (XAS): The protein samples were contacted with uranium and then concentrated to obtain $250 \mu \mathrm{L}$ of the proteinuranyl complex in the millimolar range. Two samples were prepared with the phosphorylated peptide CaM1P at $\mathrm{pH} 6$ and one at $\mathrm{pH}$ 7. The proteins at concentrations ranging from 0.17 to $0.8 \mathrm{~mm}$ were mixed with sequential additions (one every $5 \mathrm{~min}$ ) of 20 to $50 \mu \mathrm{L}$ of a $1 \mathrm{~mm}$ uranyl nitrate solution, to reach a 1:1 molar ratio. MES (20 mM, pH 6) or Tris buffer solutions (20 mM, $\mathrm{pH} 7$ ) were used to control the $\mathrm{pH}$ value of the samples. After a total peptide-uranyl contact time of about four hours, the samples were concentrated to achieve a final protein concentration of 2.2 and $3.18 \mathrm{~mm}$ for the two XAS samples at $\mathrm{pH} 6$ and of $2.54 \mathrm{mM}$ for the XAS sample at pH 7. For the non-phosphorylated peptide CaM1, two protein samples (1 mM) in MES (20 $\mathrm{mM}, \mathrm{pH}$ 6) were submitted to sequential additions of $20 \mu \mathrm{L}$ of a uranyl nitrate solution ( $1 \mathrm{mM}$ ), to reach molar ratios of $1: 1$ and 1:0.5. The samples were then concentrated and reached a peptide concentration of $3 \mathrm{~mm}$ for the $1: 1$ ratio and of $4 \mathrm{~mm}$ for the 1:0.5 ratio.

\section{Sample preparation for TRLFS}

A stock solution of $\mathrm{UO}_{2}\left(\mathrm{NO}_{3}\right)_{2}(4.2 \mathrm{mM}$, Inorganic Ventures) was used to prepare the solutions and diluted to a final concentration of $4.10^{-5} \mathrm{M}$ in samples with a CaM1 peptide concentration fixed at $1.10^{-4} \mathrm{M}$. Samples with constant peptide and uranyl concentrations were tested a various $\mathrm{pH}$ values in the range 3 to 7 . The final $\mathrm{pH}$ value of the test solutions was adjusted either with $\mathrm{NaOH}$ or $\mathrm{HNO}_{3}$ (Sigma-Aldrich). The $\mathrm{pH}$ values of the solutions were measured by using a $\mathrm{pH}$ microelectrode (semimicro, Mettler Toledo, France) and a $\mathrm{pH}$ meter (seven-multi, Mettler Toledo, France). The electrode was calibrated by using standard buffers. The $\mathrm{pH}$ measurements were performed at $20^{\circ} \mathrm{C}$ with a precision of $0.01 \mathrm{pH}$ units. The ionic strength of the solutions tested was $I=0.05 \mathrm{M}$ (corresponding to $50 \mathrm{mM}$ of MES buffer).

\section{Mass spectrometry analyses}

Mass spectrometry was used to test the purity of the phosphorylated peptide, and to analyze their integrity before and after the XAS measurements. Analyses were performed on a MicroTOF-Q (Bruker) with an electrospray ionization source. The CaM peptides were diluted in $\mathrm{CH}_{3} \mathrm{CN} / \mathrm{H}_{2} \mathrm{O}(1: 1 \mathrm{v} / \mathrm{v})$, formic acid $(0.2 \%)$. Samples were continuously infused at a flow rate of $3 \mu \mathrm{L} \mathrm{min}{ }^{-1}$. Mass spectra were recorded in the mass-to-charge $(\mathrm{m} / \mathrm{z})$ range 50-7000. MS experiments were carried out with a capillary voltage set at $4.5 \mathrm{kV}$ and an end plate off-set 
voltage of $500 \mathrm{~V}$. The gas nebulizer $\left(\mathrm{N}_{2}\right)$ pressure was set at 0.4 bar and the dry gas flow $\left(\mathrm{N}_{2}\right)$ at $4 \mathrm{~L} \mathrm{~min}^{-1}$ at $190{ }^{\circ} \mathrm{C}$. Data were acquired in the positive mode and calibration was performed by using a calibrating solution of ESI Tune Mix (Agilent) in $\mathrm{CH}_{3} \mathrm{CN} / \mathrm{H}_{2} \mathrm{O}(95: 5 \mathrm{v} / \mathrm{v}$ ). The system was controlled by the software package MicroTOF Control 2.2 and data were processed with DataAnalysis 3.4 (Bruker).

\section{FTIR spectroscopy}

The FTIR spectra were recorded on a Bruker IFS28 spectrometer equipped with a DTGS-KBr detector and an attenuated total reflection (ATR) device fitted with a nine bounce diamond microprism (4.3 mm surface diameter, ZnSe optics, SensIR Technologies, CT). Each spectrum corresponded to sixty co-added scans recorded at a resolution of $4 \mathrm{~cm}^{-1}$. All frequencies are reported with an accuracy of $\pm 1 \mathrm{~cm}^{-1}$. The FTIR spectra were recorded with peptide samples of 0.7 to $2 \mu \mathrm{L}$ deposited and dried on the ATR crystal, to reach an absorption of one at $\lambda=1650$ $\mathrm{cm}^{-1}$ (amide I region). The FTIR spectra of the CaM1-U and CaM1P-U complexes were recorded on the samples used for the EXAFS spectroscopy experiments. To calculate the difference spectra between the peptide-uranyl complexes and the peptides without uranyl, CaM1 and CaM1P samples without uranium were prepared at $\mathrm{pH} 6$ and 7 by successive dilution and concentration steps in MES (20 mM, pH 6) or Tris (20 mM, pH 7) to achieve final peptide concentrations in the millimolar range.

\section{XAS experiments}

Uranium $\mathrm{L}_{\mathrm{III}}$ edge XAS spectra were collected at room temperature at the MARS beamline at the SOLEIL synchrotron facility (ring operated at $2.75 \mathrm{GeV}$ with $400 \mathrm{~mA}$ ) dedicated to the study of radioactive materials.34 For the measurements, the monochromator was set with the $\mathrm{Si}(220)$ crystals and the mirrors with the Pt strips at $3.1 \mathrm{mrad}$. All the measurements were recorded in the fluorescence mode by using a thirteen-element high-purity germanium solidstate detector (ORTEC) and double-layered solution cells $(200 \mu \mathrm{L})$ specifically designed for radioactive samples at room temperature. $\underline{34 \mathrm{~b}}$ The energy was calibrated by measuring the $\mathrm{Y} \mathrm{K}$ edge transmission spectrum of an yttrium foil and defining the first inflection point as 17038 $\mathrm{eV}$. Eight to sixteen spectra were recorded for each sample. The EXAFS spectra were extracted and analyzed according to standard procedures by using the program EXAFSPAK $\underline{35}$ as described in detail in the following.

The EXAFS oscillations were isolated from the raw averaged data by removal of the pre-edge background, approximated by a linear function, followed by $\mu_{0}$ removal through spline-fitting techniques and normalization by using a Victoreen function. The ionization energy for the $U$ $\mathrm{L}_{\mathrm{III}}$ electron $\left(E_{0}\right)$ was arbitrarily defined as $17,166 \mathrm{eV}$ for all averaged spectra. To analyze the data, Fourier transformation of the EXAFS signals in $k^{3}$ was performed between 3.2 and 12 $\AA^{-1}$ with Hanning windows, then an $R$ range between 1 and $4 \AA$ was considered for the fit. Phases and amplitudes were calculated by using the FEFF8 code with structural models derived from the molecular dynamics simulations as well as published data on uranyl-peptide or uranyl-amino acid model compounds. $\underline{36}$ All fits included the four-legged multiple-scattering 
path of the uranyl group $\mathrm{U}-\mathrm{O}_{\mathrm{ax}}-\mathrm{U}-\mathrm{O}_{\mathrm{ax}}$. The coordination number $(N)$ of this multiple-scattering path was linked to $N$ of the single-scattering (SS) path $\mathrm{U}-\mathrm{O}_{\text {ax. }}$. The radial distance $(R)$ and the Debye-Waller factor $\left(\sigma^{2}\right)$ of the multiple-scattering path were linked at twice the $R$ and $\sigma^{2}$ of the SS path $\mathrm{U}-\mathrm{O}_{\mathrm{ax}}$, respectively. 37 During the fitting procedure, $N$ of the $\mathrm{U}-\mathrm{O}_{\mathrm{ax}} \mathrm{SS}$ path was held constant at two. The $R$ factor (normalized fit error) was provided as an indication of the fit quality.

\section{Molecular dynamics simulations}

Molecular dynamics simulations were performed by using the AMBER 10 (assisted model building and energy refinement) $\underline{38}$ package with the parm99 force field. 39 The starting structural model used for calmodulin was the three dimensional X-ray structure of Paramecium tetraurelia calmodulin with lead cations instead of calcium $\underline{40}$ (PDB ID: $1 \mathrm{~N} 0 \mathrm{Y}, 1.75 \AA$ resolution), which presents the same metal binding sequence in site I as that used in this study. Change of the amino acid sequence of the metal binding loop and introduction of phosphorylated threonine was performed by using the PyMOL software (Schrödinger: www.pymol.org). Two structural conformers corresponding to two different positions of the Tyr7 side chain were used for the MD simulations. The $\mathrm{Pb}^{2+}$ ion present in this structure was replaced by the uranyl molecule $\mathrm{UO}_{2^{2+}}$ at the same position. For the uranyl molecule, we used the parameters developed by Guilbaud and Wipff, $\underline{41}$ which have already given consistent results on energetics and hydration properties of the uranyl cation when coordinated by a variety of organic ligands, $\underline{42}$ including proteins. $\underline{3 \mathrm{~d}}$ The energy $E_{\mathrm{tot}}$ of the structural model obtained for the uranyl-peptide complexes was optimized by using the molecular dynamics simulation sequence described below.

The belly algorithm was used to allow the uranyl coordination site (sequence $n-2$ to 12 of the binding loop) to move, whereas the rest of the peptide was frozen (Figure S1 in the Supporting Information). A thermalization step was done between 0 and $300 \mathrm{~K}$, which corresponds to the temperature of our studies. Then molecular dynamics simulations were performed in the gas phase for $1 \mathrm{~ns}$ at a constant temperature of $300 \mathrm{~K}$ by using a 2 fs integration step and applying the SHAKE43 procedure in order to constrain bonds involving hydrogen atoms to their equilibrium value.

For each system, the interaction energy $E_{\mathrm{i}}$ was deduced from the difference between the energies of the separated protein $\left(E_{\mathrm{P}}\right)$ and the uranyl molecule $\left(E_{\mathrm{U}}\right)$ and that of the proteinuranyl complex $\left(E_{\mathrm{PU}}\right)[$ Eq. 1].

$E_{\mathrm{i}}=\left(E_{\mathrm{P}}+E_{\mathrm{U}}\right)-E_{\mathrm{PU}}(1)$

\section{Time-resolved laser-induced fluorescence spectroscopy (TRLFS)}

The TRLFS experiments were carried out by using a continuum R Nd:YAG laser (frequency $=10 \mathrm{~Hz}$, pulse duration $\approx 7 \mathrm{~ns}$ ) coupled with a Panther OPO as the excitation source. Detection was perfumed by a Spectra-Pro-300 monochromator (Acton Research Corporation) 
coupled with a CCD camera (Princeton Instruments). The excitation wavelength was chosen to be $\lambda=430 \mathrm{~nm}$, and the laser power was about $2 \mathrm{~mJ}$. The emission spectra were recorded by using the WINSPEC/32 software (Princeton Instruments). The fluorescence spectra had a resolution better than $0.2 \mathrm{~nm}$. The error in the fluorescence intensity was less than $5 \%$. All fluorescence intensity measurements were carried out on non-aerated freshly prepared solutions in a quartz cell at a controlled temperature of $(20 \pm 1){ }^{\circ} \mathrm{C}$. Every measurement was repeated at least three times. The fluorescence spectra integration $(\lambda=450-600 \mathrm{~nm})$ and the fluorescence decay curves were calculated with the Origin Pro8.0 software program (OriginLab corporation).

\section{Acknowledgements}

We thank Christine Battesti for the figures of the MD structural models. This work was funded in part by the Toxicologie transverse Program of CEA (CalUMo and CriRad projects), and supported by the synchrotron SOLEIL for the XAS experiments at the MARS beam line.

\section{$\underline{\text { References }}$}

1a D. Brugge, J. L. de Lemos, B. Oldmixon, Rev. Environ. Health 2005, 20, 177-193;

1b D. M. Taylor, S. K. Taylor, Rev. Environ. Health 1997, 12, 147-157.

2a C. Basset, O. Averseng, P. J. Ferron, N. Richaud, A. Hagege, O. Pible, C. Vidaud, Chem. Res. Toxicol. 2013, 26, 645-653;

2 b A. Dedieu, F. Berenguer, C. Basset, O. Prat, E. Quemeneur, O. Pible, C. Vidaud, J. Chromatogr. A 2009, 1216, 5365-5376;

2c C. Vidaud, A. Dedieu, C. Basset, S. Plantevin, I. Dany, O. Pible, E. Quemeneur, Chem. Res. Toxicol. 2005, 18, 946-953.

3a L. Le Clainche, G. Plancque, B. Amekraz, C. Moulin, C. Pradines-Lecomte, G. Peltier, C. Vita, J. Biol. Inorg. Chem. 2003, 8, 334-340;

3b B. Li, J. Raff, A. Barkleit, G. Bernhard, H. Foerstendorf, J. Inorg. Biochem. 2010, 104, 718725 ;

3c R. Pardoux, S. Sauge-Merle, D. Lemaire, P. Delangle, L. Guilloreau, J. M. Adriano, C. Berthomieu, PLoS One 2012, 7, e41922;

3d O. Pible, P. Guilbaud, J. L. Pellequer, C. Vidaud, E. Quemeneur, Biochimie 2006, 88, 16311638 ;

$3^{\text {e }}$ S. Safi, G. Creff, A. Jeanson, L. Qi, C. Basset, J. Roques, P. L. Solari, E. Simoni, C. Vidaud, C. Den Auwer, Chem. Eur. J. 2013, 19, 11261-11269;

3f F. Brulfert, S. Safi, A. Jeanson, E. Martinez-Baez, J. Roques, C. Berthomieu, P. L. Solari, S. Sauge-Merle, E. Simoni, Inorg. Chem. 2016, 55, 2728-2736.

4a F. Coppin, J. Michon, C. Garnier, S. Frelon, J. Fluoresc. 2015, 25, 569-576; 
4b C. Lebrun, M. Starck, V. Gathu, Y. Chenavier, P. Delangle, Chem. Eur. J. 2014, 20, 1656616573;

4c L. Zhou, M. Bosscher, C. Zhang, S. Ozcubukcu, L. Zhang, W. Zhang, C. J. Li, J. Liu, M. P. Jensen, L. Lai, C. He, Nat. Chem. 2014, 6, 236-241;

4d L. Le Clainche, C. Vita, Environ. Chem. Lett. 2006, 4, 45-49;

4e S. V. Wegner, H. Boyaci, H. Chen, M. P. Jensen, C. He, Angew. Chem. Int. Ed. 2009, 48, 2339-2341;

4f T. N. S. Huynh, D. Bourgeois, C. Basset, C. Vidaud, A. Hagege, Electrophoresis 2015, 36, 1374-1382;

4g M. Starck, F. A. Laporte, S. Oros, N. Sisommay, V. Gathu, P. L. Solari, G. Creff, J. Roques, C. Den Auwer, C. Lebrun, P. Delangle, Chem. Eur. J. 2017, 23, 5281-5290;

4h M. Starck, N. Sisommay, F. A. Laporte, S. Oros, C. Lebrun, P. Delangle, Inorg. Chem.2015, 54, 11557-11562.

5J. D. Van Horn, H. Huang, Coord. Chem. Rev. 2006, 250, 765-775.

6a S. O. Odoh, G. D. Bondarevsky, J. Karpus, Q. Cui, C. He, R. Spezia, L. Gagliardi, J. Am. Chem. Soc. 2014, 136, 17484-17494;

6b M. Sundararajan, A. J. Campbell, I. H. Hillier, J. Phys. Chem. A 2008, 112, 4451-4457;

6c T. Reitz, A. Rossberg, A. Barkleit, R. Steudtner, S. Selenska-Pobell, M. L. Merroun, Dalton Trans. 2015, 44, 2684-2692.

7a A. Barkleit, H. Foerstendorf, B. Li, A. Rossberg, H. Moll, G. Bernhard, Dalton Trans.2011, 40, 9868-9876;

7b M. L. Merroun, J. Raff, A. Rossberg, C. Hennig, T. Reich, S. Selenska-Pobell, Appl. Environ. Microbiol. 2005, 71, 5532-5543.

8 C. T. Yang, J. Han, M. Gu, J. Liu, Y. Li, Z. Huang, H. Z. Yu, S. Hu, X. Wang, Chem. Commun. 2015, 51, 11769-11772.

9 J. Jiang, J. C. Renshaw, M. J. Sarsfield, F. R. Livens, D. Collison, J. M. Charnock, H. Eccles, Inorg. Chem. 2003, 42, 1233-1240.

10 M. Sawicki, J. M. Siaugue, C. Jacopin, C. Moulin, T. Bailly, R. Burgada, S. Meunier, P. Baret, J. L. Pierre, F. Taran, Chem. Eur. J. 2005, 11, 3689-3697.

11 A. Koban, G. Bernhard, J. Inorg. Biochem. 2007, 101, 750-757.

12 K. Pollmann, J. Raff, M. Merroun, K. Fahmy, S. Selenska-Pobell, Biotechnol. Adv.2006, 24, $58-68$.

13 L. Qi, C. Basset, O. Averseng, E. Quemeneur, A. Hagege, C. Vidaud, Metallomics2014, 6, 166-176.

14 Q. Y. Wu, F. W. Zhai, Y. Liu, L. Y. Yuan, Z. F. Chai, W. Q. Shi, Dalton Trans. 2016, 45, 14988-14997.

15 Y. S. Babu, J. S. Sack, T. J. Greenhough, C. E. Bugg, A. R. Means, W. J. Cook, Nature 1985, 315, 37-40. 
16a M. Kakihana, T. Nagumo, M. Okamoto, H. Kakihana, J. Phys. Chem. 1987, 91, 61286136 ;

16b G. B. Deacon, R. J. Phillips, Coord. Chem. Rev. 1980, 33, 227-250;

16c K. Nakamoto, Infrared and Raman Spectra of Inorganic and Coordination Compounds Part B: Applications in Coordination, Organometallic, and Bioinorganic Chemistry, Wiley, New York, 1997.

17 S. Y. Venyaminov, N. N. Kalnin, Biopolymers 1990, 30, 1259-1271.

18a Y. N. Chirgadze, O. V. Fedorov, N. P. Trushina, Biopolymers 1975, 14, 679-694;

$18 b$ S. Y. Venyaminov, N. N. Kalnin, Biopolymers 1990, 30, 1243-1257.

19 G. S. Groenewold, W. A. de Jong, J. Oomens, M. J. Van Stipdonk, J. Am. Soc. Mass Spectrom. 2010, 21, 719-727.

20a W. E. Bull, S. K. Madan, J. E. Willis, Inorg. Chem. 1963, 2, 303;

20b Y. Feng, A. Schmidt, R. A. Weiss, Macromolecules 1996, 29, 3909-3917;

20c J. Velasquez, E. D. Pillai, P. D. Carnegie, M. A. Duncan, J. Phys. Chem. A 2006, 110, $2325-2330$.

21 E. A. Stern, J. Synchrotron Radiat. 2001, 8, 49-54.

22 M. Nedelkova, M. L. Merroun, A. Rossberg, C. Hennig, S. Selenska-Pobell, FEMS Microbiol. Ecol. 2007, 59, 694-705.

23 M. A. Denecke, T. Reich, S. Pompe, M. Bubner, K. H. Heise, H. Nitsche, P. G. Allen, J. J. Bucher, N. M. Edelstein, D. K. Shuh, J. Phys. IV 1997, 7, 637-638.

24 F. Morcillo, M. T. Gonzalez-Munoz, T. Reitz, M. E. Romero-Gonzalez, J. M. Arias, M. L. Merroun, PLoS One 2014, 9, e91305.

25 S. Suzuki, T. Yaita, Y. Okamoto, H. Shiwaku, Proceedings of the 5th Workshop Speciation, Techniques and Facilities for Radioactive Materials at Synchrotron Light Sources Actinides XAS2008, Saint-Aubin, France, 15-17 July 2008.

26 R. S. Ray, S. Kruger, N. Rosch, Dalton Trans. 2009, 3590-3598.

27a V. Vallet, U. Wahlgren, B. Schimmelpfennig, H. Moll, Z. Szabo, I. Grenthe, Inorg. Chem. 2001, 40, 3516-3525;

27b D. L. Clark, S. D. Conradson, R. J. Donohoe, D. W. Keogh, D. E. Morris, P. D. Palmer, R. D. Rogers, C. D. Tait, Inorg. Chem. 1999, 38, 1456-1466;

27c G. Schreckenbach, P. J. Hay, R. L. Martin, Inorg. Chem. 1998, 37, 4442-4451.

28 M. L. Merroun, M. Nedelkova, J. J. Ojeda, T. Reitz, M. L. Fernandez, J. M. Arias, M. Romero-Gonzalez, S. Selenska-Pobell, J. Hazard. Mater. 2011, 197, 1-10.

29a V. Eliet, G. Bidoglio, N. Omenetto, L. Parma, I. Grenthe, J. Chem. Soc. Faraday Trans. 1995, 91, 2275-2285;

29b A. Kirishima, T. Kimura, O. Tochiyama, Z. Yoshida, J. Alloys Compd. 2004, 374, 277282;

29c C. Moulin, P. Decambox, V. Moulin, J. G. Decaillon, Anal. Chem. 1995, 67, 348-353; 
29d C. Moulin, I. Laszak, V. Moulin, C. Tondre, Appl. Spectrosc. 1998, 52, 528-535.

30a G. Geipel, M. Acker, D. Vulpius, G. Bernhard, H. Nitsche, T. Fanghanel, Spectrochim. Acta Part A 2004, 60, 417-424;

30b M. Glorius, H. Moll, G. Geipel, G. Bernhard, J. Radioanal. Nucl. Chem. 2008, 277, 371377.

31 U. Wahlgren, H. Moll, I. Grenthe, B. Schimmelpfennig, L. Maron, V. Vallet, O. Gropen, J. Phys. Chem. A 1999, 103, 8257-8264.

32 P. Gans, A. Sabatini, A. Vacca, Talanta 1996, 43, 1739-1753.

33 K. Vcelakova, I. Zusková, E. Kenndler, B. Gas, Electrophoresis 2004, 25, 309-317.

34a B. Sitaud, P. L. Solari, S. Schlutig, I. Llorens, H. Hermange, J. Nucl. Mater. 2012, 425, 238-243;

34b I. LLorens, P. L. Solari, B. Sitaud, R. Bes, S. Cammelli, H. Hermange, G. Othmane, S. Safi, P. Moisy, S. Wahu, C. Bresson, M. L. Schlegel, D. Menut, J. L. Bechade, P. Martin, J. L. Hazemann, O. Proux, C. Den Auwer, Radiochim. Acta 2014, 102, 957-972.

35 G. N. George, I. J. Pickering, Stanford Synchrotron Radiation Laboratory, Stanford, CA, 1995.

36 A. L. Ankudinov, B. Ravel, J. J. Rehr, S. D. Conradson, Phys. Rev. B 1998, 58, 7565-7576.

37 E. A. Hudson, P. G. Allen, L. J. Terminello, M. A. Denecke, T. Reich, Phys. Rev. B 1996, 54, 156-165.

38 Amber, D. A. Case, T. A. Darden, T. E. I. Cheatham, C. L. Simmerling, J. J. Wang, R. E. Duke, R. Luo, M. Crowley, R. C. Walker, W. Zhang, K. M. Merz, B. Wang, S. Hayik, A. Roitberg, G. Seabra, I. Kolossváry, K. F. Wong, F. Paesani, J. Vanicek, X. Wu, S. R. Brozell, T. Steinbrecher, H. Gohlke, L. Yang, C. Tan, J. Mongan, V. Hornak, G. Cui, D. H. Mathews, M. G. Seetin, C. Sagui, V. Babin, P. A. Kollmann, University of California, San Francisco, CA, 2008.

39 T. E. I. Cheatham, P. Cieplak, P. A. Kollmann, J. Biomol. Struct. Dyn. 1999, 16, 845-862.

40 M. A. Wilson, A. T. Brunger, Acta Crystallogr. Sect. D 2003, 59, 1782-1792.

41 P. Guilbaud, G. Wipff, J. Mol. Struct. 1996, 366, 55-63.

42a M. Bühl, G. Wipff, ChemPhysChem 2011, 12, 3095-3105;

42b A. Chaumont, O. Klimchuk, C. Gaillard, I. Billard, A. Ouadi, C. Hennig, G. Wipff, J. Phys. Chem. B 2012, 116, 3205-3219;

42c S. Doudou, D. J. Vaughan, F. R. Livens, N. A. Burton, Environ. Sci. Technol. 2012, 46, 7587-7594.

43 J. P. Ryckaert, G. Ciccotti, H. J. C. Berendsen, J. Comput. Phys. 1977, 23, 327-341. 